\title{
Karine Cândido Rodrigues
}

\section{Avaliação de depressão, ansiedade, qualidade de vida e bem- estar psicológico em pacientes com diagnóstico de neoplasia endócrina múltipla tipo 2.}

Dissertação apresentada à Faculdade de Medicina da Universidade de São Paulo para obtenção de título de Mestre em Ciências

Programa de Endocrinologia

Orientador: Dr. Delmar Muniz Lourenço Junior

São Paulo

2014 


\section{Agradecimentos}

Primeiramente agradeço a Deus, por ter me dado sabedoria, confiança, humildade, paciência, amor e persistência para idealizar este trabalho e em todos os seus passos concretizá-lo de maneira tão gratificante.

Ao meu orientador, Dr. Delmar Muniz Lourenço Junior, que me acolheu como aluna, me ensinou muitas coisas, me ajudando a crescer como pesquisadora, profissional e como pessoa, se tornando um professor, um amigo, alguém que sei que sempre posso contar. Obrigada por toda sua humildade e grandiosidade como médico e como pessoa. A cada dia aprendo a te admirar mais.

Ao Prof. Dr. Sérgio P. A. Toledo, que foi meu primeiro orientador, o primeiro a acreditar neste projeto que idealizamos juntos. Que a cada dia que passou aprendi a grandeza de um ser humano que é privilegiado por uma sabedoria ímpar, uma humildade que o faz um exemplo de médico, mestre, pesquisador, e principalmente um ser humano com uma serenidade única.

À Dra. Ana A. O. Hoff que, com a sua chegada ao Ambulatório de neoplasia endócrina múltipla tipo 2, veio a somar em conhecimento e crescimento o ambulatório, e com a qual tive o prazer em trabalhar e aprender ricamente.

À Dra. Flávia Lima Coutinho, com a qual iniciei este projeto e pôde acrescentar muito em seu desenvolvimento.

Ao Prof. Dr. Alexander A. Lima Jorge, chefe da Unidade de Endocrinologia Genética (UEG), que nos apoiou em todo desenvolvimento do trabalho.

À FAPESP, pelo apoio financeiro (Bolsa de Mestrado: processo no 2012-046980) viabilizando a execução deste projeto de pesquisa.

Aos residentes que passaram pelo ambulatório de endocrinologia genética, com os quais pude trabalhar nestes 3 anos.

À psicóloga Prof. Dra. Elisa Maria Parahyba Campos, que me ensinou muito durante todos estes anos com sua experiência e me orientando na boa evolução deste estudo. 
Aos meus amigos que permanecem na UEG e também aos que já tomaram outro rumo profissional - Eliete, Elisângela, Roxane, Tomoko, Lucas, Rafael - com os quais tive o prazer de conviver todos estes anos.

Aos pacientes que aceitaram participar desta pesquisa e a todas as famílias que pude acompanhar nestes três anos.

Agradeço especialmente a minha mãe, a pessoa que mais admiro, pela sua persistência, sabedoria e grandeza como ser humano, com a qual aprendi tudo que eu sei. Que se dedicou a vida toda para eu chegar aonde eu cheguei, sempre investindo nos meus estudos e sempre me apoiando em todas as minhas decisões, abraçando todos os sonhos que sonhei.

Agradeço a minha filha de 4 patas Carolina, que é minha companheira, esteve ao meu lado durante todo este processo, com a qual conheci o amor incondicional. Por sua compreensão com a minha falta de tempo e todo seu carinho dedicado a mim. A minha alegria quando chego em casa. Mamãe ama muito você.

A minha família que amo tanto, vovó Alvarina, tia Fátima, tio Raimundo, primas irmãs: Rosângela, Kátia e Rodrigo.

As minhas queridas amigas, algumas estão perto, outras um pouco longe, mas todas muito presentes em minha vida, que me apoiaram e me ajudaram a tornar quem eu sou hoje: Simone, tão longe, mas sempre tão perto do meu coração, mesmo passando por um momento tão difícil me apoia e me fortalece sempre. Natália, Fernanda, que foram fundamentais em meus anos de faculdade, com as quais dividi tanto minha vida e que são tão importantes em todos os momentos. Minhas amigas de uma vida inteira Juliana, Kardênia, Cinthia, que amo tanto e tornam sempre minha vida mais leve.

Aos meus colegas de trabalho e amigos do ICESP, que me ajudam nesta jornada árdua de amenizar o sofrimento dos pacientes com câncer, mas que é tão gratificante e que amamos tanto: André, Lucilene, Regina, Irene, Mário Sérgio, Thabata, Isabella Drummond e ao meu coordenador Lórgio Rodriguez. 


\section{Sumário}

Lista de abreviaturas

Lista de Figuras

Lista de Tabelas

Resumo

Sumary

1. Introdução...............................................................................................................1

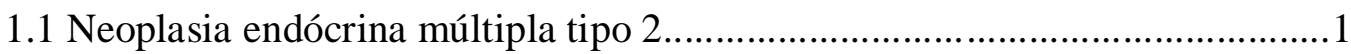

1.2 Sobre o Carcinoma Medular de Tireóide (CMT) ..........................................2

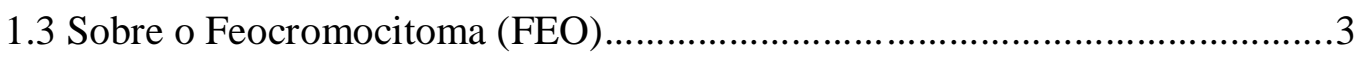

1.4 1.4 Sobre o Hiperparatireoidismo Primário (HPT) .......................................

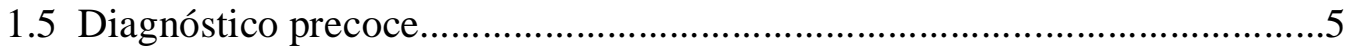

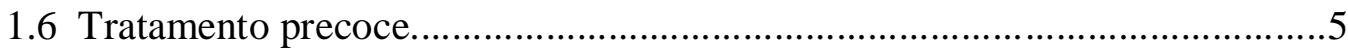

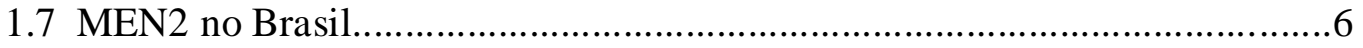

1.8 Aspectos Psicológicos dos Portadores de Câncer............................................. 7

1.8.1 Portadores de Câncer e o Ajustamento Psicológico (coping)..............7

1.8.2 Depressão em Pacientes com Câncer................................................16

1.8.3 Ansiedade em Pacientes com Câncer................................................19

1.8.4 Avaliação da Qualidade de Vida em Pacientes com Câncer............20

1.8.5 Aspectos psicológicos em neoplasias hereditárias como MEN2 2......23

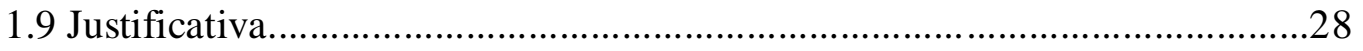

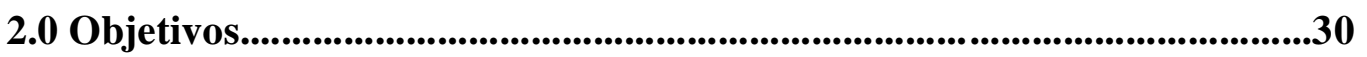

3.0 Casuística e Métodos...........................................................................31

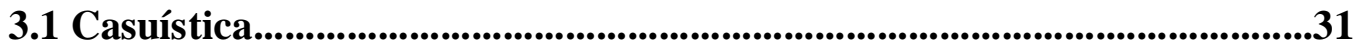

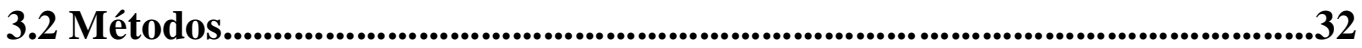

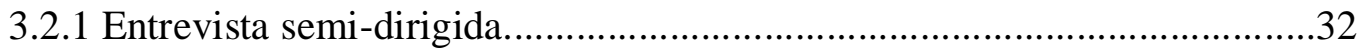

3.2.2 Escala Hospitalar de Ansiedade e Depressão (HAD).................................32

3.2.3 European Organization for Research and Treatment of Cancer Quality of 
Life Questionnair C30 (EORTC QLQC30)

3.2.4 Escala de Ajustamento Mental para Câncer: Estrutura Fatorial-(MINI-

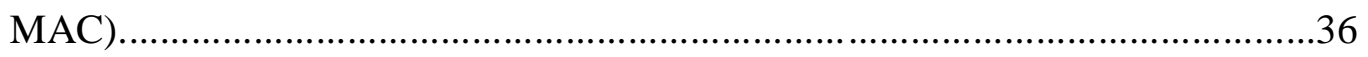

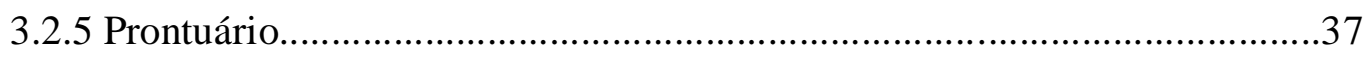

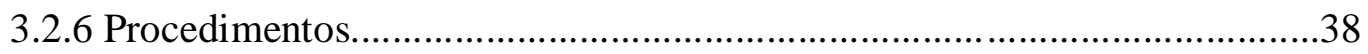

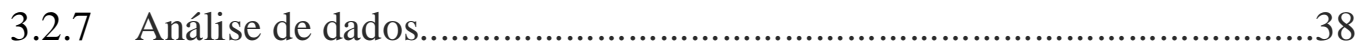

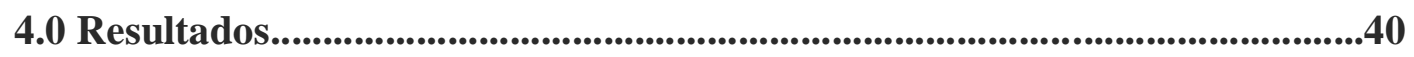

4.2 Perfil demográfico e clínico...................................................................40

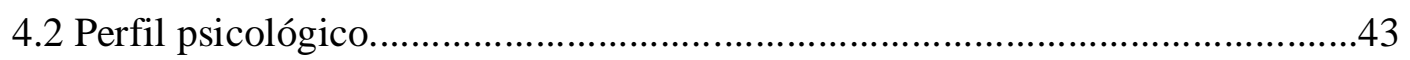

4.3 Resultados segundo uma análise descritiva.................................................55

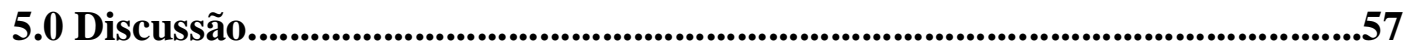

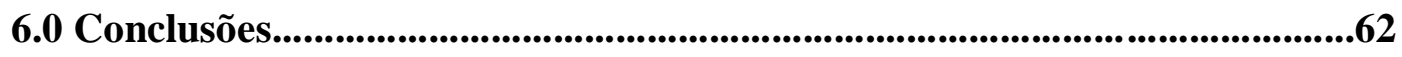

7.0 Referências Bibliográficas................................................................63

\section{Anexos}




\section{Lista de Abreviaturas}

MEN2 Neoplasia endócrina múltipla tipo 2

MEN1 Neoplasia Endócrina Múltipla tipo 1

CMT Carcinoma Medular de Tireóide

CMT-F Carcinoma Medular de Tireóide Familial

FEO Feocromocitoma

HPT Hiperparatireodismo Primário

NIH Instituto Nacional de Saúde Americano

ATA Associação Americana de Tireóide

DSM-IV Manual de Diagnóstico e Estatística de Transtornos Mentais - $4^{\mathrm{a}}$ edição

QdV Qualidade de Vida

QdRS Qualidade de Vida relacionada à saúde

HAD Escala Hospitalar de Ansiedade e Depressão

EORTC QLQ C30 European Organization for Research and Treatment of Cancer Quality of Life Questionair

MINI-MAC Escala de Ajustamento Mental para o Câncer: Estrutura Fatorial 


\section{Lista de Figuras}

Figura 1. Fórmulas para calcular os escores de QdV da Escala EORTC QLQ C30.......35

Figura 2. Prevalência de pacientes com CMT curados e não curados. .44

Figura 3. Frequência de sintomatologia ansiosa e depressiva encontrada nos 43 pacientes com MEN2 usando a escala HAD. .46 


\section{Lista de Tabelas}

Tabela 1. Mutações germinativas no gene RET identificadas nas 12 famílias com MEN2 avaliadas

Tabela 2. Domínios do instrumento genérico EORTC QLQ C30 e questões

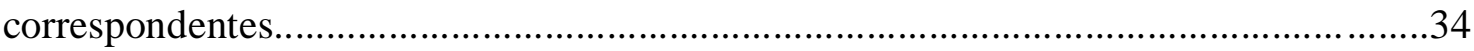

Tabela 3. Interpretação dos escores brutos de QV dos

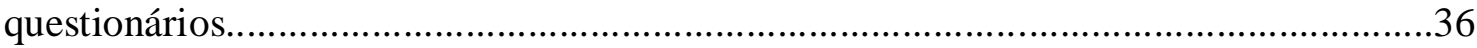

Tabela 4. Dados demográficos dos 43 pacientes com MEN2

Tabela 5. Prevalência de variantes fenotípicas e frequência de mutações germinativas RET nos 43 pacientes com MEN2.

Tabela 6. Tipos de procedimento cirúrgico conduzidos em 41 pacientes com MEN2 para tratamento de carcinoma medular de tireóide e em 17 pacientes com feocromocitoma.

Tabela 7. Reação ao diagnóstico de MEN2 e reação dos pais diante do resultado de RET positivo em seus filhos

Tabela 8. Média \pm desvio padrão dos tipos de enfrentamento avaliados nos 43 pacientes diante do diagnóstico de MEN2 pelo MINI-MAC

Tabela 9. Resultados obtidos da avaliação da qualidade de vida dos 46 pacientes com MEN2 usando EORTCQLQ-C30. .48

Tabela 10. Descrição da cura dos pacientes segundo as características pessoais, do tumor e escalas de ansiedade e depressão e resultado dos testes estatísticos bivariados.

Tabela 11. Descrição das escalas segundo a influência da cura dos pacientes e resultado dos testes estatísticos Bivariados .50

Tabela 12. Resultado da regressão logística múltipla para explicar a influência da cura dos pacientes segundo características e escalas avaliadas.

Tabela 13. Resultado das correlações positivas das escalas de ansiedade, depressão e espírito de luta com as demais escalas.

Tabela 14. Resultado das correlações negativas das escalas de ansiedade, depressão e espírito de luta com as demais escalas. 


\section{Resumo:}

Introdução: A neoplasia endócrina múltipla tipo 2 (MEN2) é uma doença hereditária autossômica dominante causada por mutação germinativa $R E T$, que cursa com carcinoma medular de tireóide (CMT), feocromocitoma (Feo) e hiperparatireoidismo. O CMT é uma neoplasia maligna, que se desenvolve já na $1^{\text {a }}$ década de vida, pouco responsiva a quimioterapia/radioterapia. Assim, tireoidectomia profilática é indicada antes dos 5 ou dos 10 anos, dependendo do códon mutado, para assegurar a cura. O CMT é um tumor de crescimento lento e os pacientes convivem com o diagnóstico de câncer por décadas. Além disto, podem desenvolver Feo, predispondoos ao risco de óbito por infarto agudo do miocárdio ou acidente vascular em idade jovem. Somam-se situações de stress como risco de transmissão aos descendentes, expectativa de resultados de exames periódicos e risco de múltiplas cirurgias. Há poucos trabalhos enfocando os aspectos psíquicos em MEN2. O doente oncológico pode desenvolver sintomas psicológicos de: ansiedade, depressão, angústia, medo de recorrência da doença, perturbações psicossomáticas, stress decorrente das cirurgias e auto-conceito negativo. Objetivos: avaliar a sintomatologia ansiosa e depressiva, a qualidade de vida, o ajustamento psicológico, a presença de culpa auto-referida pela transmissão da doença aos filhos, o conhecimento da doença e a adesão ao tratamento. Casuística: Avaliação de 43 pacientes pertencentes a 12 famílias com diagnóstico clínico e gênico de MEN2. Metodologia: Avaliação psicológica por Entrevista semidirigida, Escala Hospitalar de Ansiedade e Depressão (HAD), European Organization for Research and Treatment of Cancer Quality of Life, Escala de Ajustamento Mental para Câncer e Estrutura Fatorial. A análise dos dados foi realizada de modo quantitativo e qualitativo. Resultados: Todos os 43 pacientes com MEN2 apresentavam CMT 
(100\%) e 19 deles tinham diagnóstico prévio ou atual de Feo (44\%; 19/43). Dos 43 pacientes, $16(37 \%)$ tratados por CMT eram considerados curados (calcitonina <2 $\mathrm{pg} / \mathrm{mL}$ ) enquanto que os outros $27(63 \%)$ apresentavam persistência ou recorrência do CMT (25) ou aguardavam tratamento cirúrgico (2). Ao todo, 41 pacientes tinham história de 59 procedimentos cirúrgicos relacionados à MEN2 (1,4 cirurgia/paciente; 1 6 cirurgias). Também, 31 pacientes $(72 \%)$ responderam que tiveram medo de morrer como reação à informação do diagnóstico de MEN2. A maioria concordou em realizar o teste genético de seus filhos (21/22; 95\%). Dos 16 pacientes com MEN2 que tiveram filhos com resultados positivos para o gene RET 12 (75\%) caracterizaram a informação como "muito difícil" e "medo de perda". Um terço dos pacientes $(5 / 16 ; 31 \%)$ referiam sentimento de culpa pela transmissão genética aos seus filhos. A aderência ao uso contínuo de medicações prescritas foi elevada $(37 ; 86 \%)$. Em relação à informação sobre a doença, 32 pacientes $(77 \%)$ responderam que se sentiam bem informados.

O valor médio do estado global de saúde foi $68,1 \pm 22,3$ (variação de escore: 0-100), considerando tanto os aspectos físicos como emocionais. As frequências de sintomatologia ansiosa e depressiva encontradas pela escala HAD foram, respectivamente, $42 \%$ (18/43) e 26\% (11/43). Uma correlação positiva estatisticamente significativa foi observada entre depressão e ansiedade. Associação positiva foi observada de ansiedade e depressão com as sub-escalas: desânimo-fraqueza, preocupação ansiosa, evitamento cognitivo, fadiga, dor, insônia, náusea e vômito, dispnéia, perda de apetite e diarréia. Paralelamente, houve uma associação inversa com as sub-escalas de estado global de saúde, desempenho de atividades, funcionamento cognitivo e funcionamento emocional. Os tipos de enfrentamento mais usados pelos 
pacientes diante do diagnóstico de MEN2 foram o espirito de luta $(3,3 \pm 0,77$; variação de score: $1-4)$, o evitamento cognitivo $(2,56 \pm 1,17)$ e o fatalismo $(3,1 \pm 0,90)$. $\mathrm{O}$ espírito de luta apresentou correlação direta estatisticamente significativa com fatalismo $(r=0,369 ; p=0,015)$. Conclusões: Pela elevada prevalência, sintomatologia ansiosa e depressiva devem ser ativamente investigadas em pacientes com MEN2. O impacto de ser portador de uma doença genética predispondo a câncer gerou: medo de morte e de perda dos filhos, evitamento cognitivo, fatalismo e forte espirito de luta. Este projeto poderá propiciar o início do desenvolvimento de um ambulatório multidisciplinar envolvendo tanto médicos como psicólogos com manejo em aconselhamento genético Descritores: Neoplasia Endócrina Múltipla Tipo 2, Ansiedade, Depressão, Qualidade de Vida, Ajustamento Psicológico. 


\section{Summary:}

Introduction: Multiple endocrine neoplasia type 2 (MEN2) is autosomal-dominant hereditary cancer syndrome caused by germline RET mutation with high susceptibility to develop tumors as medullary thyroid carcinoma (MTC), pheochromocytoma (Pheo), and hyperparathyroidism. The CMT is a malignancy that develops already in the 1st decade of life, poorly responsive to chemotherapy / radiotherapy. Thus, prophylactic thyroidectomy is indicated before 5 or 10 years, depending on the mutated codon to ensure healing. The CMT is a slow-growing tumor and the patients live with the diagnosis of cancer for decades. In addition, they can develop Pheo, predisposing them to risk of death from myocardial infarction or stroke at a young age. Add to stress conditions such as risk of transmission to offspring, expectative for results of periodic examinations and risk of multiple surgeries. It is known that cancer patients can develop psychological symptoms of anxiety, depression, distress, fear of recurrence, stress for surgery and negative self-concept. However, studies focusing on the psychological aspects in MEN2 are strict and mainly related with the time of RET genetic testing and genetic counselling. Objectives: To assess anxious and depressive symptoms, quality of life, psychological adjustment, presence of guilt by self-reported disease transmission to children, knowledge of disease and treatment adherence. Methods: Evaluation of 43 patients from 12 families with clinical and genetic diagnosis of MEN2. Methodology: Psychological assessment by semi-directed interview, Scale Hospital Anxiety and Depression (HAD), European Organization for Research and Treatment of Cancer Quality of Life Scale, Mental Adjustment to Cancer and Factor Structure. Data analysis was performed quantitatively and qualitatively. Results: All 43 patients had CMT MEN2 (100\%) and 19 had previous or current diagnosis of pheochromocytoma (44\%, 19/43). Of the 43 patients, 16 (37\%) treated by CMT were considered cured (calcitonin $<2 \mathrm{pg} / \mathrm{ml})$ while the other $27(63 \%)$ had persistent or recurrent MTC (25) or were awaiting surgery (2). Altogether, 41 patients had a history of 59 surgical procedures related to MEN2 (1.4 Surgery / Patient, 1-6 surgeries). Altogether, 31 patients (72\%) responded that they were afraid to die as a reaction to the diagnosis of MEN2 information. Most agreed to conduct genetic testing of their children (21/22, 95\%). Of the 16 patients with MEN2 who had children with positive results for the RET gene 12 
(75\%) characterized the information as "very difficult" and "fear of loss". One third of patients $(5 / 16,31 \%)$ reported feelings of guilt by genetic transmission to their children. Adherence to continuous use of prescribed medications was high $(37,86 \%)$. The frequencies of anxious and depressive symptoms found by the HAD scale were, respectively, $42 \%(18 / 43)$ and $26 \%$ (11/43). A statistically significant positive correlation was observed between depression and anxiety. There was a positive association of anxiety/depression with the sub-scales: weakness-dejection, anxious preoccupation, cognitive avoidance, fatigue, pain, insomnia, nausea and vomiting, dyspnea, loss of appetite and diarrhea. Inverse association occurred with the subscales of general health, performance activities, cognitive functioning and operation emocional. The more types of coping used by patients before the diagnosis of MEN2 were fighting spirit (3.3 \pm 0.77 ; change of score: $1-4)$, cognitive avoidance $(2.56 \pm 1.17)$ and fatalism $(3.1 \pm 0.90)$. The mean global health status was $68.1 \pm 22.3$ (range of scores: 0-100), considering both the physical and emotional aspects. Conclusions: Due to its high prevalence, anxious and depressive symptoms should be actively investigated in patients with MEN2. The impact of being a carrier of a genetic disorder predisposing to cancer generated: fear of death and loss of children, cognitive avoidance, fatalism, strong fighting spirit. This project will promote the development of a multidisciplinary clinic involving both physicians and psychologists with management in genetic counseling.

Descriptors: Multiple Endocrine Neoplasia Type 2, Anxiety, Depression, Quality of Life, Psychological Adjustment. 


\section{INTRODUÇÃO}

\subsection{Neoplasia endócrina múltipla tipo 2}

A neoplasia endócrina múltipla tipo 2 (MEN2), também conhecida como Síndrome de Sipple, é uma síndrome genética que se caracteriza pela associação clínica de neoplasias endócrinas acometendo as glândulas tireóide, adrenal e paratireoides (1$3)$.

Estudos de transfecção com DNA advindos de linfoma humano em células NIH3T3 revelaram a presença de foco de proliferação tumoral, associada a diferentes seqüências genéticas de DNA. Entre estas seqüências, uma apresentava-se em todas as amostras e foi denominada RET - "rearranged during transfection" (4). Em 1987, estudos de ligação em famílias grandes com MEN2 associaram esta síndrome com a região centromérica do braço longo do cromossomo 10q11.2 (5,6). Em 1989, o protooncogene RET foi mapeado no cromossomo 10q11.2 de humanos (7). Em 1993, mutações germinativas ativadoras no gene RET, um proto-oncogene localizado no cromossomo 10q11.2, foram associadas como responsáveis por MEN2 $(8,9)$.

MEN2 é transmitida por um padrão de herança autossômica dominante. Assim, a presença de uma mutação no gene RET em heterozigose já é suficiente para potencialmente causar a doença e os filhos de um pai ou mãe afetado têm $50 \%$ de possibilidade de herdarem a mutação (8-18).

Mutações no gene RET induzem a proliferação anormal de células de origem neuroendócrina, tais como: células $\mathrm{C}$ ou parafoliculares da tireóide; células cromafins da camada medular da adrenal e; células principais e oxifílicas das paratireóides (8-18). 
Assim, MEN2 compreende basicamente um grupo de 3 fenótipos:1) MEN2A OMIM\#171400), que envolve tumores como carcinoma medular de tireóide (CMT), feocromocitoma (FEO) e hiperparatireoidismo primário (HPT); 2) MEN2B (OMIM\#162300), que se caracteriza por apresentar CMT, FEO, ganglioneuromas de mucosas e anormalidades constitucionais como hábito marfanóide, além da ausência de HPT e; 3) CMT familial isolado (CMT-F; OMIM\#155240), onde há somente a presença do CMT (2). Mais recentemente, CMT-F tem sido considerado como uma variante fenotípica de MEN2A com baixa penetrância de outros tumores do que uma entidade clínica distinta (8-18).

\subsection{Sobre o Carcinoma Medular de Tireóide (CMT)}

MEN2 tem uma prevalência estimada de 1:30.000 indivíduos sendo que o CMT é a manifestação clínica mais frequente nesta síndrome estando virtualmente presente em todos os pacientes com MEN2A e MEN2B e na maioria dos portadores de mutação germinativa RET associada com CMT-F (10-18).

O CMT é um tumor altamente maligno que corresponde a cerca de 4-10\% de todas as patologias malignas que acometem a tireóide. A forma esporádica representa 70-75\% dos casos de CMT enquanto que 25-30\% são hereditários e associados com MEN2A, MEN2B ou CMT-F (10-18).

O CMT tem origem nas células parafoliculares (células C), que compreendem cerca de $1 \%$ da massa tecidual da tireóide. Estas células estão dispersas por toda a glândula, embora, uma maior concentração delas seja encontrada na região posterior dos lobos superiores da tireóide. CMT associado à MEN2, ao contrário do que ocorre com CMT esporádico, se desenvolve a partir de hiperplasia das células $\mathrm{C}$ que é considerada 
sua lesão precursora tumoral. Assim, a presença de hiperplasia de células C primária associada com CMT em espécimes cirúrgicos é um achado que sugere CMT hereditário $(10-18)$.

O CMT se caracteriza pela hipersecreção de calcitonina e, por isto, este hormônio é classicamente considerado como o marcador tumoral desta neoplasia maligna. Assim, as dosagens séricas de calcitonina são utilizadas tanto para a detecção precoce da doença como para a avaliação de cura ou de recorrência auxiliando no manejo clínico dos pacientes (10-18).

O risco de CMT em pacientes com MEN2A é quase 100\%, mas a maioria dos casos-índices é diagnosticada tardiamente, geralmente na terceira década de vida (1018). Apesar destes tumores se apresentarem com padrão de crescimento lento, a ocorrência de metástases precoces, tanto regionais como à distância, são frequentes (1018). Metástases regionais ocorrem em 50-70\% dos pacientes com nódulos tireoidianos palpáveis (> $1 \mathrm{~cm})$. Metástases à distância ocorrem predominantemente para fígado, pulmões, ossos e cérebro (10-18). CMT é classicamente considerado uma neoplasia maligna quimio- e radio-resistente. Por estas características, o CMT é a principal causa de morte em MEN2. Assim, a detecção precoce e tratamento imediato por meio da tireoidectomia total preventiva ou curativa são essenciais para diminuição da morbidade e mortalidade (10-18).

\subsection{Sobre o Feocromocitoma (FEO)}

Feocromocitomas são tumores de células cromafins da medula adrenal que apresentam comportamento benigno em $90 \%$ dos casos podendo ser esporádicos ou familiais. Os FEOs associados à MEN2 são praticamente benignos, de localização 
exclusiva nas adrenais e com ocorrência de tumores bilaterais, sincrônicos ou assincrônicos, em até $65 \%$ dos pacientes. Apesar da natureza benigna, a secreção excessiva de catecolaminas pelo tumor pode conduzir ao risco elevado de infarto agudo do miocárdio e de acidentes vasculares cerebrais em jovens gerando elevada morbidade e mortalidade relacionada à doença se for diagnosticado tardiamente (10-18).

A penetrância deste tumor é dependente do códon mutado podendo ser ausente ou alcançar uma penetrância elevada como é o caso de famílias com a mutação no códon 634 (até 50\%) ou com associação desta mutação com uma variante genética no códon 791 (80\%), recentemente descrita pelo nosso grupo (19). Em MEN2A, o CMT é a primeira e única manifestação em $50 \%$ dos casos. FEO pode ser diagnosticado junto com CMT em 40\% dos casos de MEN2A sendo a primeira e única manifestação clínica em somente $10 \%$ dos casos (18). Nos pacientes com mutações associadas com FEO, o diagnóstico deste tumor deve ser feito ou excluído antes de submeter o paciente a qualquer tratamento cirúrgico de CMT pelos riscos peri-operatórios associados com FEO (10-18). Assim, nestes casos a adrenalectomia para tratamento do FEO precede o tratamento cirúrgico do CMT. O diagnóstico de FEO permite o uso de drogas alfaadrenérgicas que controlam as crises paroxísticas adrenérgicas e a hipertensão arterial associada à hipersecreção de catecolaminas preparando o paciente de forma mais segura para a adrenalectomia (10-18).

\subsection{Sobre o Hiperparatireoidismo Primário (HPT)}

O HPT associado à MEN2 é usualmente subclínico e, em geral, uma ou duas glândulas são afetadas. A penetrância de HPT também é, como no FEO, dependente do 
códon mutado com uma penetrância máxima ao redor de $30 \%$. Assim, HPT está associado principalmente com pacientes apresentando mutações no códon 634 (10-18).

\subsection{Diagnóstico Precoce}

Na era pós-genômica, a abordagem terapêutica do MEN2 e, especialmente do CMT, sofreu grande impacto, uma vez que os testes genéticos permitiram discriminar precocemente, portadores de não portadores de mutação no gene RET. O teste genético que inclui a análise para mutações do RET é considerado de alta precisão e pode ser usado para identificar quem herdou o gene mutado antes do início dos sintomas. Amostras de DNA são usualmente extraídas do núcleo de leucócitos do sangue periférico, mas também podem ser obtidas das vilosidades coriônicas da placenta, com a finalidade do diagnóstico intra-uterino (10-18).

\subsection{Tratamento precoce}

Desde 2001, vários consensos internacionais têm sido publicados por médicos/pesquisadores com experiência em MEN2 visando orientar e aperfeiçoar o manejo clínico e genético tanto dos pacientes com MEN2 como de seus familiares sob risco de doença $(10,11,15,18)$. Dentre eles, o seguido pela maioria dos serviços é o recomendado pela Associação Americana de Tireóide (ATA) publicado em 2009 (15). Segundo o consenso da ATA, pacientes com mutações no códon 634 do RET, categorizadas como nível de agressividade C para CMT, devem ser operados (tireoidectomia total) ao redor dos 3-5 anos de idade. Os com mutação no códon 918 (nível D), devem ser operados tão breve quanto possível e preferencialmente antes dos 6 meses de idade; os casos com mutação nos códons 608, 618 e 620, entre outras (nível 
B) devem ser operados ao redor dos 5 anos; e os com mutações nos códons 804 e 791, entre outras (nível A), devem ser operados abaixo dos 10 anos de idade $(15,18)$.

A conduta estabelecida pelos Consensos foi baseada no fato de que a agressividade e o início do CMT estão intrinsicamente relacionados com o tipo de mutação identificada se estabelecendo uma estreita correlação entre o genótipo e o fenótipo. A tireoidectomia profilática é reconhecida como o procedimento terapêutico mais eficaz para CMT, uma vez que este procedimento está associado com taxas de cura próximas de $100 \%$ e sobrevida igual a da população geral. Após serem operados, estes pacientes devem ser acompanhados periodicamente pelo médico pelo risco potencial de recorrência, principalmente, se cirurgia não pôde ser realizada nas idades preconizadas pelos Consensos e para investigação periódica ativa de FEO (10-18).

Os pacientes são considerados bioquimicamente curados quando seus níveis basais de calcitonina sérica são $<2$ pg/ml (10-18).

\subsection{MEN2 no Brasil}

No Brasil, as neoplasias endócrinas múltiplas foram investigadas por vários grupos, sendo um deles o do Hospital das Clínicas da Faculdade de Medicina da Universidade de São Paulo (HC-FMUSP). O nosso grupo tem analisado vários aspectos desta patologia, tais como: o impacto da análise de mutação do RET no manejo clínico da MEN2 (13); o rastreamento gênico da MEN2, na experiência da Unidade de Endocrinologia Genética, LIM-25, Endocrinologia, do HC-FMUSP (14); a alta penetrância do FEO em pacientes com mutações RET 634/791 (19), entre outros aspectos da MEN2 ou do CMT (20-24) também foram estudadas incluindo participação em Consórcio internacional para estudo e caracterização do fenótipo de mutações no 
exon 10 do gene RET (25). Neste estudo, foi incluída a apresentação do fenótipo de família brasileira seguida no HCFMUSP com cerca de 40 familiares afetados representando a maior família descrita com esta mutação (C620R). Assim, nosso grupo tem se constituído em um dos locais de referência tanto para o diagnóstico clínico e gênico bem como para o tratamento de MEN2 no Brasil.

\subsection{Aspectos Psicológicos dos Portadores de Câncer}

Nos últimos anos, com a melhora efetiva do tratamento de vários tipos de câncer e consequente aumento substancial da sobrevida, tem se observado uma preocupação constante com os aspectos psicológicos e com a qualidade de vida de pacientes oncológicos tanto durante como após o tratamento. Também, cada vez se torna mais frequente, casos de pacientes que adquirem estabilização da doença com uso de drogas modernas, denominadas drogas-alvo. Tais pacientes convivem por vários anos com esta situação de terem um câncer avançado e estável. Além disto, com o medo diário de perda do controle e avanço da doença, secundário a possível perda de eficiência destes tratamentos mais modernos. Assim, situações como avaliação de aspectos psíquicos como depressão, ansiedade, qualidade de vida e ajustamento psicológico tem se tornado parte integrante da tomada de decisão do tratamento de pacientes oncológicos.

\subsubsection{Portadores de Câncer e o Enfrentamento Psicológico (coping)}

É recente o interesse pela investigação das relações existentes de fatores emocionais com a incidência e a evolução do câncer. Esta abordagem vem fornecendo subsídios psicológicos para a prevenção, adaptação emocional e social do indivíduo nas diferentes etapas do tratamento oncológico. Diante disto, observou-se que pacientes com um mesmo diagnóstico e prognóstico médico tinham evoluções diferentes, pois uns 
viviam mais do que outros. Esta observação instigou o radioterapeuta americano Simonton (26) a se perguntar sobre se fatores psicológicos estariam influenciando nestes resultados. Embora características genéticas e epigenéticas individuais e relacionados ao próprio tumor bem como fatores ambientais não possam ser excluídas, percebeu-se que aqueles pacientes que evoluíram melhor tinham em comum o desejo de não querer morrer por ter, por exemplo, um projeto inacabado em andamento e que os prendia à vida (26).

Pode-se, assim, verificar por estas associações biopsicossociais, que um aspecto importante a ser investigado nos pacientes com câncer é o Coping e o Ajustamento Mental. Segundo Greer e Watson (27) ajustamento mental ao câncer pode ser definido como respostas cognitivas e comportamentais dadas por um indivíduo diante do diagnóstico de câncer $(27,28)$. Estes autores explicam que o ajustamento mental envolve tanto a avaliação como os doentes percebem as implicações do câncer como as suas reações para reduzir a ameaça trazida pela doença $(27,28)$. Folkman e Lazarus (26) definem coping como esforços cognitivos e comportamentais para gerir exigências específicas, internas e/ou externas, que são avaliadas como excedendo ou que estão nos limites dos recursos do indivíduo (26).

Como explicam Schnoll et al. (29), o diagnóstico e tratamento do câncer é um acontecimento ameaçador que desencadeia um processo de avaliação e uma resposta de coping, os quais, por sua vez, determinam o resultado emocional da experiência (29).

Nesta direção, foi observada uma correlação positiva da dimensão "preocupação ansiosa" avaliada pela Escala de Ajustamento Mental para Câncer (Mini-Mac) com a 
sintomatologia ansiosa, avaliada pela Escala de Ansiedade e de Depressão Hospitalar (HAD) (29).

Pacientes que se mostraram deprimidos, com profunda apatia e com uma atitude de desistência diante da vida evoluíram pior. Entre estes, Carvalho (30) refere que Simonton observou que alguns afirmavam querer viver, mas adotavam atitudes contraditórias em relação a esta afirmação, mantendo hábitos e estilos de vida pouco saudáveis. Os pacientes que evoluíram melhor tinham como característica achar que de alguma forma podiam influenciar o curso de suas doenças. Adotavam uma atitude muito mais ativa em relação às suas vidas, em relação à doença e aos tratamentos médicos. Eram pessoas mais participativas e não viam o processo de cura como algo a que devessem se submeter passivamente, mas como algo que podiam participar de forma ativa. O autor observou então que aspectos de personalidade e estados emocionais influenciavam sobre condições físicas e que era necessário considerar o indivíduo como um todo (30).

A doença é uma experiência e uma metáfora, uma mensagem que precisa ser ouvida e dissipada. Os pacientes podem desenvolver maior autoconfiança quando se conectam com seus sentimentos, reconhecendo-os e aceitando-os e, também, quando percebem que podem lidar com emoções como o medo. Esta percepção dos sentimentos e consequente aquisição de autoconfiança são capazes de quebrar o ciclo da depressão e desesperança e de aumentar sua capacidade de lidar consigo diante das situações com as quais se confrontam em suas vidas (30).

Pensamentos e sentimentos não provocam e nem curam o câncer (30), mas podem influenciar no seu desenvolvimento ou na sua regressão. Assim, sentimentos, 
como o stress, afetam a química do organismo (que afeta o desenvolvimento ou a regressão do tumor), assim como a química do corpo afeta os sentimentos. Enfim, todos os aspectos do ser humano interagem e se influenciam mutuamente. A escuta e o acolhimento (holding) são imprescindíveis mesmo diante de um pedido para morrer (pela dor, abandono, etc).

Elisabeth Kubler-Ross em sua obra "Sobre a morte e o morrer" aponta cinco estágios pelos quais passa o doente desde o diagnóstico até a morte:1) Negação e isolamento: como "Não pode ser comigo"; "não tenho nada"; 2) Raiva: quando a negação não é mais possível surgem sentimentos de raiva e de revolta. "Por que eu?" Esta raiva pode estar relacionada à impotência e à falta de controle da própria vida; 3 ) Barganha: estratégia do paciente tentando certo acordo para adiar um desfecho inadiável; 4) Depressão: momento do contato efetivo com a doença e as suas perdas do corpo, das finanças, da família, do emprego e do lazer. Tirar o paciente do seu processo de enlutamento pode perturbar o seu processo, pois o procedimento mais adequado parece ser o de facilitar a sua expressão; 5) Aceitação: os pacientes que viveram a sua doença e receberam apoio nos estágios anteriores podem chegar a uma aceitação (31).

Embora nem todos os pacientes passem por todos os estágios até a aceitação nem os vivenciem sempre na ordem descrita, a autora apontou a importância de se perceber que os pacientes têm necessidades diferentes nos vários estágios da doença e que temos que aproximar os nossos olhos e ouvidos do corpo de nosso paciente e não das máquinas (31).

Destaca-se aqui que os membros da família, principalmente os cuidadores mais próximos, ao receberem o diagnóstico de uma doença grave, passam pelos mesmos 
estágios que o paciente e as formas de enfrentamento vão depender da estrutura de cada um e da relação entre eles. É frequente surgir perda em vida, luto antecipado, ambivalência de sentimentos, impotência, culpa e tentativa de reparação (31).

O paciente oncológico, angustiado pelo medo da morte, fica voltado para si mesmo ou utiliza mecanismos psicológicos de defesa, que tem uma dupla finalidade: lutar contra a angústia desencadeada diante da ameaça da doença e estabelecer uma nova maneira de relacionamento com o meio e consigo mesmo (30). Em geral, o primeiro mecanismo de defesa é a negação. Inicialmente a negação pode ser uma crosta protetora, mas se persistir por longo período enfraquece o relacionamento e impede o paciente de assumir uma atitude mais responsável. Se o paciente procurar auxílio nesta fase de negação, a psicoterapia terá como meta auxiliá-lo a aceitar a realidade e a iniciar o tratamento propriamente dito. Durante a negação podem, também, ocorrer mecanismos relacionados a uma postura onipotente, com atuações maníacas, intercalados por momentos de depressão (30). O terapeuta pode propor-se a ajudar o paciente a perceber melhor estas oscilações entre onipotência e depressão e ensiná-lo a vivenciar melhor os momentos de depressão profunda por se dar conta de seu estado. Em geral, o paciente alcança uma vida de melhor qualidade se consegue ter uma conscientização deste estado de doença e uma elaboração mais aprimorada da sua situação. Como resultado do tratamento, os pacientes ficam mais sensíveis, permitem que suas emoções apareçam e se relacionam de maneira mais genuína com seus familiares (30).

Muitos pacientes fazem uso da sublimação e outros, quando a situação física permite, passam a ajudar voluntariamente outros pacientes ou a fazer uma prestação de 
serviço social, sentindo-se úteis para os outros. Referem, também, sensação de bemestar e conforto diante desta atividade social voluntária (30).

Cada um de nós tem um universo muito rico, repleto de dor, alegria, esperança, tristeza, medo, orgulho, solidão, relacionamentos, isolamento, ódios, amores e tudo o mais que artistas, escritores e poetas nos dizem fazer parte da condição humana. O paciente com câncer possui maior quantidade de emoções do que é capaz de expressar. A ausência de uma saída para cargas emocionais intensificadas afeta o corpo da pessoa (32). Como exemplo disto, foi observado que o desenvolvimento de câncer em algumas pessoas foi precedido pela perda de um relacionamento vital (32).

Em um estudo com um grupo de mulheres com câncer se descobriu que essas pacientes possuíam um elevado grau de "autocontrole emocional, idealismo e senso de responsabilidade" (32). Estas características são tidas como virtudes, quando no contexto apropriado, mas até uma virtude pode ser levada a extremos. Se a responsabilidade e o autocontrole forem rigidamente mantidos, em detrimento da expressão de sentimentos verdadeiros, uma parte do eu é negada. Quando as tensões não são liberadas e a raiva é reprimida, podem tornar-se mais fortes. Sabemos que isso acontece no desenvolvimento de úlceras. Será que podemos negar a possibilidade de que isso também aconteça no desenvolvimento do câncer? (32)

Observou-se também que quando a raiva, a tristeza ou a preocupação não encontram uma válvula de escape, acabam afetando o corpo, e se houver uma tendência latente para desenvolver um câncer, a incapacidade para expressar seus sentimentos irá atingir o corpo em algum ponto vulnerável (32). 
Atualmente se torna cada vez mais claro que as explicações físicas - meio ambiente, infecções ou genética - não oferecem uma resposta global em relação ao processo de adoecimento. Assim, um número cada vez maior de médicos e psicólogos buscam informações adicionais com relação à influência do stress, da personalidade, das emoções no desenvolvimento de câncer. Como exemplo disto, observou-se que parecia haver uma correspondência geral entre o ritmo de desenvolvimento do câncer e o tempo transcorrido desde que o indivíduo perdera o senso de significado da vida representado por um relacionamento vital (32).

A intervenção psicológica apresenta-se como um recurso que amplia os limites de ação no atendimento das necessidades que surgem em cada momento da trajetória do paciente. Isto se reflete desde a situação de diagnóstico, passando por tratamentos que podem ou não resultar em cura, chegando às situações posteriores de adaptação do paciente ou da família às sequelas concretas ou subjetivas com que se deparam (32).

A família é um organismo essencialmente dinâmico em que a doença de um de seus membros altera seu funcionamento. A notícia de que um ente querido sofre de câncer pode produzir um grande impacto, por isso indica-se que além de focar a atenção na ajuda à pessoa doente, haja também a indicação de se atentar para os efeitos do trauma do diagnóstico sobre outros membros da família (32).

A ênfase do trabalho em equipe multiprofissional com o paciente oncológico deve ser colocada no conforto, na dignidade e no autorrespeito do paciente, bem como propiciar a ele o direito de receber explicações a respeito de sua doença, participando ativamente das decisões quanto ao seu tratamento. Assim os pacientes não temerão o isolamento, o abandono e a rejeição, mas ficarão confiantes na honestidade e na 
habilidade dos profissionais, e com a certeza de que se algo puder ser realizado com eles, será em conjunto, respeitando as deliberações. Não podemos esquecer que o paciente tem uma percepção do que está acontecendo com ele e com as pessoas a sua volta. O que ele precisa é de pessoas que possam lhe dar afeto e apoio nestes momentos difíceis de sua vida. (32)

A teoria psicanalítica nos auxilia a fazer uma leitura da situação da história do paciente e da família e algumas intervenções interpretativas. A compreensão do momento como um todo e das emoções incluindo as do terapeuta são imprescindíveis. Os aspectos transferenciais e contratranferenciais deverão guiar nossas intervenções e nossa atuação. Os imprevistos são inúmeros como nas análises, e as interrupções podem acontecer por morte. As fantasias de morte, por exemplo, podem estar presentes em várias pessoas e refletirem uma percepção da realidade (32).

O psicólogo, em sua atividade, propõe-se a: auxiliar o paciente e sua família quanto as suas angústias de negação ou evitação do diagnóstico; compartilhar o sofrimento ficando ao lado do paciente, algumas vezes até em silêncio, num momento que pode ser de desespero e confusão para que este possa enfrentar a sua realidade; possibilitar que o paciente se conecte com seus temores gradualmente, expressando suas fantasias através das palavras para que possam ser trabalhadas; refletir junto ao paciente sobre a qualidade de suas relações com os outros e consigo próprio; auxiliar os pacientes a encontrarem recursos internos e a valorizarem aspectos que até então estavam despercebidos; trabalhar suas expectativas de recuperação e em relação ao seu futuro; auxiliar o paciente a participar ativamente de seu tratamento; auxiliar o paciente a encontrar atividades significativas em sua vida e adotar hábitos mais saudáveis; 
auxiliar os pacientes e familiares a lidarem com os diversos sentimentos e emoções mobilizadas, principalmente a depressão; trabalhar o temor da morte, tendo em vista que embora possa ser inevitável, raramente o doente ou a família se encontram preparados e; principalmente, enfocar o trabalho com o paciente na preservação de qualidade de vida (33).

Uma revisão extensa foi publicada, embasada na literatura psicológica do câncer, como uma tentativa de fazer um esboço para se entender melhor o processo de câncer através de uma interpretação particular tanto em termos de culpa como do papel das perdas na vida destas pessoas. Nesta revisão, a repressão e a negação observada nos pacientes com câncer foi entendida como mecanismos atribuídos à hostilidade e constrição (31). A relação entre constrição e câncer é uma tentativa explicativa tendo como referência o sistema científico biológico (imunológico). Quanto à hipótese da perda relacionada à depressão, revisaram autores do século XVIII e XIX e encontraram a melancolia e a tristeza como antecedentes de câncer. Encontraram, também, pesquisas contemporâneas que enfatizaram o papel da depressão imediatamente após uma separação de uma pessoa significativa ou uma perda de objetivo de vida. Citam um estudo que descreve que o paciente oncológico tem um padrão centrífugo de relação familiar, onde a precoce individuação, o mútuo isolamento e a distância de uns membros dos outros é a regra. Em outro estudo citado nesta revisão, era ressaltada a personalidade específica e características defensivas nos pacientes oncológicos, cujas hipóteses são as de que os pacientes com câncer perderam a consciência de suas próprias necessidades ocultas bem como de seus desejos (31). 


\subsubsection{Depressão em Pacientes com Câncer}

A depressão pode ser definida como um estado afetivo doloroso, desprazeroso, provocado às vezes pela perda de um objeto, frustração, fracasso, etc., (34). Nas ocasiões em que está se realizando o trabalho de luto, qualquer objeto que recorde em algo o objeto perdido, reativa a saudade deste. Se a saudade aumenta e a realidade mostra a impossibilidade de satisfação, produz-se a dor psíquica.

Para o psicólogo, depressão refere-se a qualquer decréscimo no desempenho cognitivo, perceptivo ou motor. A depressão é uma das doenças mais comuns a que os seres humanos estão sujeitos. Paradoxalmente é, provavelmente, o sintoma mais frequente negligenciado e, mesmo quando reconhecido, é provavelmente o sintoma isolado mais incorretamente tratado na prática clínica. Sentimento de tristeza, desapontamento e frustração são acompanhamentos normais da condição humana e o limite entre humor normal e depressões anormais permanece indefinido (34).

Com respeito à depressão em pacientes com câncer, a literatura demonstra que essa associação existe, seja a depressão como um fator de pré-disposição à doença ou como um acometimento posterior ao diagnóstico $(35,36)$. Como síndrome, a depressão não só inclui mudanças do humor ou sintomas psíquicos, mas também outras alterações, como: psicomotoras (aumento da latência entre perguntas e respostas), cognitivas (déficit de atenção e concentração), da esfera instintiva e neurovegetativa (fadiga, desânimo), ideativas (pessimismo, ideias de arrependimento e culpa), autodesvalorização (sentimento de baixa autoestima, sentimento de insuficiência) e sintomas psicóticos (delírios e alucinações) (37). Porém, diagnosticar a depressão em pacientes com câncer é bastante difícil devido à existência de alguns sintomas, como 
alteração de apetite e da autoestima, da sua imagem corporal, diminuição de energia e libido e presença de insônia, que se sobrepõem aos sintomas e /ou características comuns do câncer e do seu tratamento $(36,37)$.

Os pacientes com câncer apresentam uma incidência de depressão maior do que a população geral, segundo Carvalho (32). A prevalência de depressão na população geral é de aproximadamente $3 \%$, aumentando para $10 \%$ entre a população atendida em algum serviço de saúde. O autor adota como referência os critérios do DSM-IV (Manual de Diagnóstico e Estatística de Transtornos Mentais - $4^{\mathrm{a}}$ Edição), mas com algumas adaptações. Os sintomas de perda de peso, distúrbios de sono, fadiga ou perda de energia e diminuição da habilidade de pensar ou de se concentrar perdem a especificidade nos pacientes com câncer, pois estes podem ser desencadeados por outras causas devido à doença e não à depressão. $\mathrm{O}$ autor coloca que nestes pacientes a perda de peso deve ser substituída pela presença de aspecto deprimido, a insônia pode ser substituída pela diminuição dos contatos sociais, a fadiga substituída por sentimentos de autopiedade ou pessimismo, e ainda a diminuição de concentração ou habilidade de pensar ser substituída por perda de reatividade e dificuldade de se animar. A dor é um elemento a ser considerado ao se fazer diagnóstico psiquiátrico, e é sempre recomendável que a dor seja removida antes de firmar este tipo de diagnóstico. Alguns pacientes podem apresentar quadro de depressão em função dos próprios tratamentos quimioterápicos ou com corticosteroides (32).

Pacientes com câncer que apresentam episódios depressivos recorrentes tem maior possibilidade de terem tido episódios depressivos na juventude. Outro ponto destacado por Carvalho (32), quanto à instalação da depressão ou seu agravamento, é a 
fragilidade de uma rede social de apoio, já que pessoas com estrutura psíquica frágil, em geral, têm dificuldade em estabelecer uma rede de apoio significativa. Alguns pacientes por não quererem ser um peso para a família, não partilham seus sentimentos, aumentando o isolamento e a depressão. Em geral, os homens apresentam maior isolamento social do que as mulheres além da preocupação com inabilidade para o trabalho.

A depressão também aparece quando o paciente recebe o diagnóstico (35), pois alguns pacientes não conseguem aceitá-lo e não conseguindo negar a doença, se veem obrigados a reconhecê-la deprimindo-se diante dos acontecimentos. Pode aparecer no início da doença ou surgir após a cirurgia e outros tratamentos, exigindo a cada momento novas readaptações (35).

Os sintomas depressivos são relativamente comuns e frequentes em pacientes com câncer, mas é uma minoria que se torna clinicamente deprimida (36). Em seu artigo, o autor revisa informações básicas para auxiliar a identificar riscos de uma depressão maior, inclusive riscos de suicídio. O autor ainda aponta que tristeza é uma emoção normal e esperada nos pacientes com câncer, que aos poucos vão acomodando suas circunstâncias de saúde com o suporte familiar e dos amigos e, através das várias opções de tratamento, podem reestabelecer algum senso de equilíbrio. Entretanto, pacientes que vivenciam a depressão clínica ou uma síndrome depressiva experimentam uma variedade de sintomas físicos e psíquicos que enfraquecem as capacidades funcionais e ocupações sociais. Os fatores que aumentam o risco dos pacientes oncológicos desenvolverem depressão clínica são: história de depressão com dois ou 
mais episódios durante sua vida e pacientes que tem história familiar de depressão ou suicídio (36).

Pacientes com dor severa são mais propensos à depressão do que pacientes com pouca dor (36). A depressão pode ser uma amplificação da experiência de dor, pois a mesma afeta a qualidade de vida e diminui o senso de controle do paciente, tornando-o mais vulnerável e menos capaz de receber e de se beneficiar de um suporte familiar e de amigos (36).

\subsubsection{Ansiedade em Pacientes com Câncer}

A ansiedade pode ser definida como um estado emocional desagradável no qual existem sentimentos de perigo iminente, caracterizado por inquietação, tensão ou apreensão. É causada, geralmente, por um conflito intrapsíquico inconsciente ou não reconhecido. A ansiedade está associada a um padrão característico de descarga do sistema nervoso autônomo, envolvendo a frequência respiratória e cardíaca, palidez cutânea, sensação de boca seca, aumento de sudorese e distúrbios musculoesqueléticos, envolvendo tremores e sensação de fraqueza (37).

A ansiedade é observada em grande parte dos pacientes com câncer, podendo estar associada com o período de espera entre o diagnóstico, cirurgia e o tratamento (38). A ansiedade é um fenômeno natural que faz parte do nosso sistema de alarme e regula os nossos medos sendo que a sua intensidade determina a diferença entre o normal e o patológico (37).

Nós experimentamos profundas emoções em resposta ao tratamento de uma doença como o câncer. As implicações e incertezas deste diagnóstico podem intensificar emoções. O choque ou descrença encontrada na descoberta do tumor se associam com 
sintomas como ansiedade, tristeza, irritabilidade, perda do sono e distúrbios no apetite. Em geral, os pacientes oncológicos expressam vários medos que incluem: medo da inabilidade, da perda prévia de posição ou função ocupada; dependência ou perda do controle e; medo de perder a vontade de viver. Alguns pacientes se preocupam com o fato que suas vivências em relação ao adoecimento irão se tornar intoleráveis, que poderão ser abandonados pelos outros e temem antecipar o curso da sua morte. Entretanto, depois de várias semanas, muitos pacientes experimentam certas condições de readaptação para enfrentamento da doença (39).

Segundo Carvalho, o índice de transtornos ansiosos nos pacientes com câncer tem prevalência maior que na população geral, que é de aproximadamente $20 \%$ (32).

Estudos que abordam a depressão e ansiedade juntas sugerem que o estado emocional do paciente, sua autoestima, sua percepção sobre imagem corporal, entre outros fatores encontram-se relacionados $(30,40,41)$.

\subsection{4- Avaliação da Qualidade de Vida em Pacientes com Câncer}

O diagnóstico de câncer suscita reações tanto no doente como nos familiares que vão de choque, revolta, descrença e raiva à aceitação. Estas reações fazem parte de uma adaptação à doença e a nova situação de saúde. Contudo, depois do choque inicial, os doentes têm que aprender novas linguagens e saberes que os tornem aptos a lidar com a doença, o meio hospitalar, os exames de diagnóstico e os tratamentos a que são submetidos (16).

Vários parâmetros importantes têm de ser tomados em consideração no processo do cuidar do doente com câncer como o choque do diagnóstico, a dor e o stress decorrente das terapêuticas, as restrições ao seu desempenho físico e intelectual, suas 
limitações nas atividades diárias, a estigmatização social e o lidar com situações que põem em risco a vida ou que vão diminuir a sua esperança de vida (42). Desta forma, é necessário que além da avaliação clássica de Qualidade de Vida (QdV) seja também efetuada a avaliação da Qualidade de Vida Relacionada com a Saúde (QdVRS), sendo o seu aumento, ou pelo menos a sua manutenção, um objetivo fundamental a atingir sempre que se estabelece uma estratégia terapêutica para um doente oncológico (43).

Cella e Cherin (44) salientam que para os indivíduos saudáveis a noção de QdV se refere a conceitos como riqueza, lazer, autonomia, liberdade, ou seja, tudo o que proporcione um cotidiano agradável. No entanto, num doente a QdV é um conceito relativo. Estes autores definem a QdVRS como sendo "a apreciação e satisfação que o doente tem com o seu funcionamento atual quando comparado com aquele que ele considera possível ou ideal” $(45,46)$.

Nesta perspectiva, a avaliação da QdVRS nos doentes oncológicos é cada vez mais valorizada devido a fatores como: o avanço tecnológico na detecção e tratamento da doença, que permitem extensão da sobrevivência e aumento do número de sobreviventes; e a preocupação com a autonomia e direitos dos doentes (43). Além disso, Kaplan (33) e Santos (47) salientam que tratar a doença pode não ser relevante, se isso não corresponder a um aumento de QdVRS. Atualmente, é clara a grande importância em ajudar o doente a gerir os efeitos secundários da sua patologia e adaptar-se às alterações permanentes na sua imagem corporal, função ou atividade social, para uma manutenção da qualidade de vida global.

Segundo a perspectiva de Selby (48), os doentes com câncer experimentam a ansiedade, depressão e a cólera, e por isso, “(...) o bem-estar emocional é um fator 
independente e muito determinante na qualidade de vida do doente oncológico, que requer avaliação”. Neste âmbito, Aaronson (46) salienta que a QdVRS tornou-se de forma crescente um objetivo prioritário dos serviços de saúde, paralelamente à prevenção de doenças, efetivação da cura e alívio de sintomas ou prolongamento da vida humana.

Existe uma multiplicidade de fatores que influenciam a QdVRS, tais como; localização e estadiamento da doença $(46,47)$; tipo de tratamento recebido (44) e; fatores demográficos, tais como idade, sexo, estado civil, grau de escolaridade e rendimentos (36). Para Pimentel (42), não existe uma única definição de QdVRS, mas podemos descrevê-la, de forma funcional, como a percepção dos doentes sobre as suas capacidades em quatro grandes dimensões: bem-estar físico e atividades cotidianas; bem-estar psicológico; relações sociais e; sintomas. Neste âmbito, Albert (49), também define a QdVRS como um conceito multidimensional, que traduz o bem-estar subjetivo do doente nas suas vertentes físicas, psicológicas e sociais, que pode ser subdividido em três domínios. O domínio físico refere-se à percepção que o doente tem da sua capacidade em realizar as suas atividades diárias. O domínio social refere-se à capacidade do doente se relacionar com membros da família, vizinhos, amigos, e outros. Por fim, o domínio psicológico incorpora aspectos do bem-estar emocional e mental, como depressão, ansiedade, medo, raiva, entre outros.

Segundo Pimentel (42), a medida objetiva e precisa da QdVRS é imperiosa, devendo ser um critério de primeira magnitude na avaliação dos resultados da terapêutica oncológica. É salientado que durante as terapêuticas efetuadas com intuito curativo, a avaliação da QdVRS é muito importante, pois permite identificar qual a 
percepção que o doente tem dos efeitos somáticos e psicossociais induzidos pela terapêutica.

Os eventos a que um doente está sujeito por causa da sua doença (sintomas, efeitos colaterais, experiências traumatizantes, benefícios da terapêutica), formam uma malha complexa que vai ser integrada pelo doente. A importância que este atribui a cada um dos eventos vai influenciar o domínio físico e psicológico da QdVRS. Indiretamente, essas influências vão repercutir no domínio social e econômico (42).

\subsubsection{Aspectos psicológicos em neoplasias hereditárias incluindo MEN2}

Em contraste ao vasto corpo de pesquisas clínicas e genéticas, informações sobre os aspectos psíquicos e suas implicações sobre a qualidade de vida em pacientes com diagnóstico de MEN2 são limitadas. Em revisão da literatura, pudemos identificar somente quatro trabalhos envolvendo aspectos psicológicos e MEN2. Todos estes trabalhos foram publicados por um grupo holandês que tem experiência reconhecida no seguimento e tratamento de famílias portadoras de MEN2. Tais trabalhos enfatizaram os aspectos psicológicos relacionados tanto com a expectativa do resultado genético para o gene RET bem como o impacto psicológico após notificação deste resultado em indivíduos sob risco de MEN2 (50, 51, 52, 16).

Outro foco destes estudos foi como abordar e realizar o aconselhamento genético de famílias com MEN2. Lips et al (16) em uma revisão sobre aconselhamento genético em MEN2 externam a experiência de seu grupo no seguimento de pacientes e de seus familiares sob risco de MEN2 referentes aos aspectos psicossociais. Nesta revisão, os autores (16) observaram que, diante do diagnóstico de MEN2, a maioria dos pacientes sente-se inseguro e com perda de autoestima. Muitos pacientes evoluem com problemas 
psicológicos, como depressão, negação, ansiedade, comportamento de evitação, ataques de pânico e reações de perda. Eles, também, sofrem com as expectativas prévias de sofrimento e de incertezas quanto ao futuro que, por sua vez, podem repercutir na qualidade de vida (16).

O primeiro estudo das experiências psicossociais de pacientes e cuidadores em famílias com MEN2 foi relatado quatro anos antes da descoberta da relação entre o gene RET e MEN2 (53). Neste estudo, foram pesquisados 32 pacientes com MEN2 e seus familiares para determinar o grau de satisfação com a informação médica; identificar problemas encontrados em relação ao diagnóstico e ao tratamento de câncer hereditário; investigar sobre as mudanças na qualidade de vida tanto dos pacientes com MEN2 como de seus familiares e; avaliar a preferência nas atividades de acompanhamento. Os entrevistados, pacientes e familiares, criticaram a forma como os problemas emocionais e clínicos das crianças afetadas foram tratados e relataram dificuldade para falar sobre a doença. Observou-se neste estudo que os membros afetados das famílias com MEN2 discutiam os problemas clínicos mais facilmente do que os problemas emocionais. Constataram-se conflitos no relacionamento entre os casais, apontando para as incertezas geradas na vivência familiar diante da doença genética. Outro achado importante deste estudo foi a necessidade de se oferecer mais informações aos pais com o objetivo de facilitar a tomada de decisões sobre opções de manejo e tratamento de seus filhos portadores de MEN2A (53).

O diagnóstico de um membro com MEN2 causa um enorme impacto na família (16). Na Holanda, a experiência é de que as famílias se isolam e mantêm a doença como um segredo de família (16). O psicólogo pode ter um papel importante no 
acompanhamento destes pacientes e seus familiares, reduzindo a angústia e ansiedade que este tipo de diagnóstico pode causar nestes pacientes (54).

A MEN2 tem uma prevalência baixa na população geral, porém nas famílias afetadas, existe um risco elevado de desenvolver a doença (16). É muito importante identificar precocemente a doença tanto para planejar a intervenção cirúrgica como para diminuir a ansiedade associada à expectativa em relação ao tratamento. Isto auxilia na tomada de decisão e planejamento, melhorando o prognóstico bem como a qualidade de vida dos pacientes (16).

Sintomas de sofrimento psicológico como ansiedade e depressão têm sido estudados em indivíduos apresentando câncer, especialmente em pacientes com câncer de mama, pâncreas e com leucemias $(55 ; 32)$. No entanto, a ansiedade e a depressão têm sido pouco estudadas entre os pacientes que convivem câncer hereditário. De acordo com os dados de uma meta-análise, os níveis de sintomatologia ansiosa e angústia psicológica dos pacientes com câncer de mama foram semelhantes aos da população normal, enquanto que os níveis de depressão eram mais elevados, utilizando a Escala hospitalar de Ansiedade e Depressão HAD (32). Alguns anos após o diagnóstico, a maioria dos pacientes estará livre de depressão e terá uma qualidade de vida, avaliada através da Escala European Organization for Research and Treatment of Cancer Quality of Life Questionnair (EORTC-QLQC30), similar àquela antes do diagnóstico de câncer, desde que fique livre de recorrência (32).

Outro estudo, realizado na Suécia, avaliou a qualidade de vida em pessoas que vivem com outra doença neoplásica hereditária, a neoplasia endócrina múltipla tipo 1 (MEN1) (56). Para esta análise, este grupo foi comparado com dados normativos da 
população geral. Além da qualidade de vida, também foi estudada a ansiedade e depressão, tanto em um momento de internação para tratamento oncológico clínico ou cirúrgico como em domicílio seis meses após a alta hospitalar. O principal resultado deste estudo é que as medidas dos resultados psicossociais (ansiedade, depressão, intrusão, fuga) mudaram apenas marginalmente entre a internação e seis meses após alta hospitalar. A depressão aumentou apenas para pacientes que tem uma doença ativa e que estavam em tratamentos agressivos como quimioterapia ou uso de interferon. Comparando com amostras de base populacional "esperada", a pontuação da Qualidade de Vida $(\mathrm{QdV})$ em pacientes com MEN1 foi menor que o da população geral tanto em aspectos relacionados à saúde como sociais. O otimismo no hospital foi um preditor único de saúde mental, mas não de outras variáveis restantes na QdV global em casa seis meses depois. A prevalência de sintomatologia depressiva, avaliada pela HAD, nos pacientes em remissão de doença foi de $23 \%$. Já nos pacientes em fase crítica do tratamento e em uso de interferon ou quimioterapia, a sintomatologia depressiva foi mais prevalente (53\%). A grande maioria destes pacientes com MEN1 foi considerada como pessimistas segundo a análise do estudo (74\%). Este trabalho também evidenciou que os pacientes com doença em estágio mais avançado e em tratamento ativo podem precisar de suporte psicológico durante esta fase crítica (56).

Tumores neuroendócrinos gastrointestinais, em geral, podem ter um comportamento biológico similar ao encontrado em pacientes com CMT. Assim, estes pacientes podem conviver por vários anos com a presença de tumor maligno em estágio avançado pela presença de metástases à distância e com doença estável tanto na vigência como na ausência de tratamento oncológico. Estudo de qualidade de vida 
utilizando a escala EORTC QLQ-C30 em pacientes sobreviventes de tumores neuroendócrinos gastrointestinais concluiu que esta escala foi adequada na avaliação e que tais pacientes, na sua maioria, apresentavam uma qualidade de vida classificada como relativamente boa (57).

A informação pode reduzir a angústia da incerteza, e é considerada como fator relevante no que se refere à ajuda necessária aos doentes com neoplasias genéticas e seus familiares para lidar com uma doença à qual está associada uma ameaça grave. Os doentes e as suas famílias ficam menos ansiosos em relação aos efeitos secundários dos tratamentos quando estão prevenidos sobre estratégias de autocuidado (54).

Os profissionais de saúde, ao fornecerem informações sobre a doença, tratamentos e efeitos secundários ajudam a integração e colaboração dos doentes nos cuidados de saúde, permitindo que façam parte do tratamento. A informação funciona como catalisadora, permitindo aos doentes e famílias se adaptarem mais facilmente à doença e se sentirem menos ameaçados (58).

Além da orientação acerca da causa da doença e de seu risco de recorrência, o sofrimento decorrente do diagnóstico de câncer põe o indivíduo diante de impotências e limites corporais, expondo-o diante da perspectiva da morte e precipitando defesas e estratégias psicológicas de enfrentamento que muitas vezes excedem a dimensão do organismo. A doença, as prescrições e os medicamentos adquirem sentido na dinâmica subjetiva, não dizendo respeito apenas à enfermidade como objeto de investigação biomédica (59).

O psicólogo pode ter um papel importante no acompanhamento das famílias portadoras de neoplasias hereditárias e o seu trabalho pode ter como atividades 
prioritárias os seguintes aspectos: a compreensão de aspectos médicos que permitam esclarecer aos pacientes, através do uso de uma abordagem psicológica, dúvidas sobre o diagnóstico, a causa provável do transtorno, seus mecanismos de herança e os possíveis tratamentos a serem realizados; a verificação da adesão ao tratamento médico de indivíduos portadores de mutação ou afetados; a orientação dos portadores quanto aos riscos de gerarem descendentes afetados geneticamente e as implicações psicológicas deste fato do ponto de vista de todos os envolvidos; a orientação quanto à conveniência de interromper, ou não, uma gestação de acordo com as determinações legais; a reabilitação psicossocial do paciente, visando seu ajustamento pessoal e/ou profissional; o atendimento e acompanhamento psicológico do paciente, portador de doença genética, e de seu grupo familiar; a contribuição e o estímulo às discussões éticas que envolvem o planejamento e a manipulação de material genético em indivíduos humanos $(54,58)$.

Motta (54) enfatiza que o trabalho do psicólogo com pacientes com neoplasias genéticas não se esgota com a explicação da causa da doença e de seu risco de recorrência, ou ocorrência. Acredita-se que seja necessária a execução de um processo assistencial, com entrevistas e sessões terapêuticas, para tratar toda a problemática associada à ansiedade, culpa, depressão, fantasias e outras manifestações mórbidas do psiquismo do paciente com diagnóstico de doenças genéticas.

\subsection{JUSTIFICATIVA}

Diante do exposto, observa-se que estudos acerca dos aspectos psíquicos são limitados em pacientes com MEN2. Estes estudos enfatizaram, principalmente, as reações psíquicas frente aos testes de diagnóstico genético e orientações de manejo de aconselhamento genético de famílias com MEN2. Um único estudo, através de 
avaliação qualitativa, abordou sobre depressão, ansiedade, bem estar psicológico e qualidade de vida de pacientes com MEN2. O estudo atual aborda estes aspectos psíquicos em pacientes com MEN2, através de avaliação qualitativa por meio de entrevista semi-dirigida e por avaliação quantitativa, usando questionários direcionados para avaliação de sintomatologia ansiosa e depressiva (HAD), de ajustamento psicológico (MINI-MAC) e de qualidade de vida (EORTC QLQC30) que são adequados para abordagem de pacientes oncológicos. É possível que o aumento da compreensão de aspectos de ordem psicológica vivenciados por pacientes com MEN2 e seus familiares possa potencialmente propiciar o aprimoramento da assistência oferecida a estes pacientes. 


\section{2- OBJETIVOS:}

\section{1-Objetivos principais:}

Este estudo se propõe a avaliar em 43 pacientes com diagnóstico clínico e gênico de MEN2:

2.1.1 - a sintomatologia ansiosa.

2.1.2- a sintomatologia depressiva.

2.1.3- a qualidade de vida.

2.1.4- o ajustamento psicológico (coping).

\section{2- Objetivos secundários:}

2.2.5- a presença de culpa autorreferida relacionada à transmissão parental.

2.2.2- o grau de conhecimento da doença. 


\section{3-CASUÍSTICA E MÉTODOS}

\section{1-Casuística}

A casuística é composta por 43 pacientes com diagnóstico clínico e gênico de MEN2. Todos estes pacientes são seguidos no ambulatório de MEN2 da Unidade de Endocrinologia Genética, Disciplina de Endocrinologia do Hospital das Clínicas da FMUSP.

Estes pacientes são membros de 12 famílias com MEN2 não relacionadas, que foram caracterizadas geneticamente pela identificação de mutação germinativa RET. As mutações identificadas são apresentadas na tabela 1. O rastreamento gênico dos familiares sob risco de MEN2 possibilitou a identificação de cerca de 150 indivíduos portadores de mutação germinativa $\operatorname{RET}(18,19)$.

Tabela 1. Mutações germinativas no gene RET das 12 famílias com MEN2 avaliadas.

\begin{tabular}{|c|c|c|c|}
\hline Famílias com MEN2 & Exon & \multicolumn{2}{|c|}{ Mutação RET } \\
\hline 1 & \multirow{3}{*}{10} & c. $1858 \mathrm{~T}>\mathrm{C}$ & Cys620Arg \\
\hline 2 & & c. $1858 \mathrm{~T}>\mathrm{C}$ & Cys620Arg \\
\hline 3 & & c. $1858 \mathrm{~T}>\mathrm{C}$ & Cys620Arg \\
\hline 4 & \multirow[t]{4}{*}{11} & c. $1900 \mathrm{~T}>\mathrm{C}$ & Cys634Arg \\
\hline 5 & & c. $1900 \mathrm{~T}>\mathrm{C}$ & Cys634Arg \\
\hline 6 & & c. $1900 \mathrm{~T}>\mathrm{C}$ & Cys634Arg \\
\hline 7 & & c.1901G $>A$ & Cys634Tyr \\
\hline 8 & \multirow[t]{3}{*}{$11 / 13$} & c.1901G $>A$ & Cys634Tyr/Tyr791Phe \\
\hline 9 & & c. $1901 \mathrm{G}>\mathrm{A}$ & Cys634Tyr/Tyr791Phe \\
\hline 10 & & c.1901G $>A$ & Cys634Tyr/Tyr791Phe \\
\hline 11 & 14 & c. $2410 G>A$ & Val804Met \\
\hline 12 & 16 & c. $2753 \mathrm{~T}>\mathrm{C}$ & Met918Thr \\
\hline
\end{tabular}

3.2-Métodos 
Trata-se de um estudo transversal que foi baseado na aplicação de instrumentos de avaliação psicológica que se seguem: entrevista semi-dirigida; escala Hospitalar de Ansiedade e Depressão (HAD); European Organization for Research and Treatment of Cancer Quality of Life Questionnair C30 (EORTC QLQC30) e; Escala de Ajustamento Mental para Câncer: Estrutura Fatorial (MINI-MAC).

\subsection{1- Entrevista semi-dirigida:}

Foi aplicada uma entrevista semi-dirigida com roteiro previamente elaborado (anexo A) que contém 14 questões. A entrevista semi-dirigida permite certa liberdade para que o paciente exponha suas questões. $\mathrm{O}$ pesquisador pode interromper para fazer perguntas que esclareçam lacunas e que orientem o assunto para uma ou outra direção.

Por meio desta entrevista, a amostra foi caracterizada quanto ao sexo, idade, estado civil, grau de instrução, ocupação e número de filhos. Várias questões adicionais foram abordadas como: ter ou não ter filhos diante do diagnóstico de MEN2; sentimento de culpa relacionada com a transmissão genética; estado atual da doença (ativa; em remissão); como o paciente encara a doença e as alternativas de tratamento como a realização de cirurgias ou eventual quimioterapia; grau de adesão ao tratamento e; avaliação do nível de informação sobre a doença.

\subsection{2-Escala Hospitalar de Ansiedade e Depressão (HAD)}

A Escala Hospitalar de Ansiedade e Depressão (Hospital Anxiety and Depression Scale, $H A D$ ) (Anexo B) foi utilizada para avaliar tanto a sintomatologia ansiosa como a depressiva. A HAD é uma escala que avalia separadamente a sintomatologia depressiva e a ansiosa tanto em pacientes com outras doenças instaladas como em indivíduos não considerados doentes (39). Ela tem a vantagem na aplicação 
em pacientes com diagnóstico de câncer por não incluir sinais e sintomas físicos que poderiam interferir na avaliação de depressão e ansiedade.

A HAD é composta por 14 questões, das quais sete são relacionadas à ansiedade (HAD-A) e sete à depressão (HAD-D) (60). O entrevistado atribui nota de zero a três para cada uma das perguntas, perfazendo totais que podem variar de 0 a 21 em cada subescala. Pontuação de oito ou mais, tanto na subescala de ansiedade quanto na de depressão, é sugestiva de transtorno de ansiedade e de depressão, respectivamente (61). Apesar da pontuação, a HAD não tem como objetivo quantificar a gravidade do sintoma. A escala HAD foi validada no Brasil em uma enfermaria de clínica médica (62).

\subsection{3- European Organization for Research and Treatment of Cancer Quality of Life}

\section{Questionnair C30 (EORTC QLQC30)}

A escala EORTC QLQC30 (Anexo C) foi utilizada para avaliar a qualidade de vida. A EORTC QLQC30 é um questionário de qualidade de vida relacionado com o estado de saúde para uso específico em pacientes com câncer e que foi devidamente validado para a população brasileira (63). O QLQC30 adota o modelo de QdV multidimensional enquanto que o grupo EORTC o define em relação aos elementos centrais do estado funcional, sintomas do câncer e específicos do tratamento, angústia psicológica, interação social, impacto financeiro, estado de saúde percebida e Qualidade de vida geral (64).

O EORTC QLQC30 é composto por 30 itens com o objetivo de avaliar aspectos gerais da QdV de pacientes oncológicos. As opções de resposta para 28 questões são: não (1), pouco (2), moderadamente (3) e muito (4). Nas duas últimas perguntas, o 
entrevistado deve avaliar "sua saúde global" e "sua qualidade de vida geral" na última semana, com uma variação de 1 (péssima) à 7 (ótima). Os domínios deste instrumento são divididos em 3 escalas: estado de saúde geral, escalas funcionais, escalas de sintomas (Tabela 2).

Tabela 2. Domínios do instrumento genérico EORTC QLQ C30 e questões correspondentes.

\begin{tabular}{|c|c|}
\hline Domínios & Questões \\
\hline Estado de saúde global & 29,30 \\
\hline \multicolumn{2}{|l|}{ Escalas funcionais } \\
\hline Função Física & 1 a 5 \\
\hline Desempenho Funcional & 6,7 \\
\hline Função Emocional & 21 a 24 \\
\hline Função Cognitiva & 20,25 \\
\hline Função Social & $26,27,28$ \\
\hline \multicolumn{2}{|l|}{ Escalas de Sintomas } \\
\hline Fadiga & $10,12,18$ \\
\hline Náusea e Vômito & 14,15 \\
\hline Dor & 9,19 \\
\hline Dispnéia & 8 \\
\hline Insônia & 11 \\
\hline Perda do Apetite & 13 \\
\hline Constipação & 16 \\
\hline Diarréia & 17 \\
\hline
\end{tabular}


As fórmulas para calcular os escores da EORTC QLQ são específicas para cada escala: escala de saúde global; escalas funcionais; escalas de sintomas (Figura 1).

Figura 1. Fórmulas para calcular os escores de QdV da Escala EORTC QLQ C30.

\section{Technical Summary}

In practical terms, if items $I_{1}, I_{2}, \ldots I_{n}$ are included in a scale, the procedure is as follows:

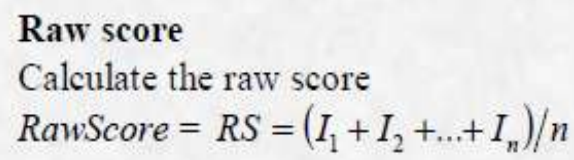

Linear transformation

Apply the linear transformation to $0-100$ to obtain the score $S$,

Functional scales:

$$
S=\left\{1-\frac{(R S-1)}{\text { range }}\right\} \times 100
$$

Symptom scales / items: $S=\{(R S-1) /$ range $\} \times 100$

Global health status / QoL: $S=\{(R S-1) /$ range $\} \times 100$

Range is the difference between the maximum possible value of $R S$ and the minimum possible value. The QLQ-C30 has been designed so that all items in any scale take the same range of values. Therefore, the range of $R S$ equals the range of the item values. Most items are scored 1 to 4 , giving range $=3$. The exceptions are the items contributing to the global health status / QoL, which are 7-point questions with range $=6$, and the initial yes/no items on the earlier versions of the QLQ-C30 which have range $=1$.

(EORTC QLQ C-30 Scoring Manual) (45).

Através de uma transformação linear, os escores brutos são padronizados e os escores relativos são obtidos para ambos os questionários, que variam de 0 a 100 . Para o estado de saúde global e para os domínios das escalas funcionais, zero representa o pior estado de QdV e 100 representa a melhor QdV. Enquanto que, para a escala de sintomas, quanto maior for o escore (máximo 100), pior será o nível de sintomas ou problemas e, por consequência, pior será a QdV (Tabela 3). 
Tabela 3. Interpretação dos escores brutos de QdV dos questionários.

\begin{tabular}{ccc}
$\begin{array}{c}\text { PIOR QdV } \\
\text { (escore relativo) }\end{array}$ & $\begin{array}{c}\text { MELHOR QdV } \\
\text { (escore relativo) }\end{array}$ \\
\hline Zero & Estado de Saúde Global & 100 \\
Zero & Funcional & 100 \\
100 & Sintomas & Zero \\
\hline
\end{tabular}

EORTC QLQ C-30 Scoring Manual) (45)

\subsection{4- Escala de Ajustamento Mental para Câncer: Estrutura Fatorial - (MINI-MAC)}

Foi utilizada a escala MINI-MAC (anexo D) para avaliar as estratégias de coping de evitamento utilizadas pelos pacientes oncológicos. Coping de evitamento é a tendência para bloquear ou ignorar problemas ou emoções. A MINI-MAC permite analisar a forma como os pacientes enfrentam o diagnóstico e o tratamento do câncer.

A MINI-MAC foi desenvolvida por Watson (28) a partir da experiência com a versão original da MAC (27) da qual se aproveitaram 16 dos 40 itens da MAC original. Este grupo desenvolveu a nova versão porque reconheceu que a anterior tinha limitações na avaliação das estratégias de coping. Esta escala foi validada por PaisRibeiro, Ramos e Samico (65) para a língua portuguesa.

O Mini-Mac é um instrumento de auto-preenchimento com 29 itens, distribuídos por cinco sub-escalas, que cobrem as dimensões: 1) Desânimo-Fraqueza (ex. "Sinto que a vida não tem esperança") que inclui os itens 1, 2, 6, 13, 16, 18, 22 e 28 e é caracterizada pelo pessimismo e a ausência de estratégias de combate ativo da doença; 2) Preocupação Ansiosa (ex. "Estou preocupado que a doença volte a aparecer"), que inclui os itens $8,10,12,14,15,23,27$ e 29 e se caracteriza por uma 
ansiedade persistente; 3) Espírito de luta (ex. "estou determinado a vencer a minha doença"), que inclui os itens $3,19,20$ e 26 e se refere a um padrão de resposta que caracteriza uma atitude otimista na qual a doença é encarada como um desafio havendo a crença de algum controle sobre o processo e percurso da doença; 4) Evitamento Cognitivo (ex. "faço um esforço positivo para não pensar na minha doença"), que inclui os itens 4, 9, 21 e 24 e remete para a recusa do conhecimento do diagnóstico e; 5) Fatalismo (ex. Entreguei-me nas mãos de Deus"), que inclui os itens 5, 7, 11, 17 e 25 e diz respeito à aceitação passiva da doença. Cada item é uma afirmação que descreve reações dos doentes ao câncer. Para cada um dos itens, os sujeitos assinalam o seu grau de concordância, numa escala do tipo likert de quatro pontos (1= Não se aplica de modo nenhum a mim; 2= Não se aplica a mim; 3= Aplica-se a mim; 4= Aplica-se totalmente a mim). É uma escala multidimensional que não permite a obtenção de um resultado total.

A maior pontuação representa o maior endosso da resposta de ajuste. Os domínios podem ser pontuados separadamente através de simples adição. Uma vez que cada domínio consiste em um número diferente de pontos que é calculado, a pontuação de cada domínio é obtida calculando os escores médios, ou seja, dividindo a soma pelo número de itens.

\subsection{5- Prontuário}

Os dados clínicos dos pacientes foram obtidos através de informações contidas nos prontuários médicos. Tais dados foram utilizados para se obter os parâmetros clínicos da doença com o intuito de caracterizar diferentes subgrupos de MEN2 e os tratamentos realizados pelos pacientes.

Foram investigados os seguintes parâmetros: 
-Tipo de MEN2: MEN2A, MEN2B e CMT-F; Tipos de cirurgias realizadas; Realização de quimioterapia e radioterapia; Medicamentos utilizados no tratamento; Estágio da doença: 1-Vive sem doença, 2- Recidiva Local 3- Metástase à distância 4Presença de Feo 5- Presença de Carcinoma Medular.

\subsection{6- Procedimentos}

Os pacientes foram informados acerca do estudo por meio da leitura do termo de consentimento livre e esclarecido (ANEXO E) no final da consulta de seguimento clínico realizada no Ambulatório de Endocrinologia do HC-FMUSP.

A pesquisa se iniciou após a assinatura do termo de consentimento. Foram aplicadas a entrevista semi-dirigida e em seguida foi solicitado que o paciente respondesse a escala para avaliar a sintomatologia Ansiosa e Depressiva (HAD); a Qualidade de Vida (EORTC QLQ C30) e, por último, uma escala para avaliar o ajustamento mental (MINI-MAC).

\subsection{7- Análise de dados}

A análise dos dados foi realizada de modo qualitativo e quantitativo. As questões da entrevista semi-dirigida foram analisadas com a técnica de Análise de Conteúdo também denominada Análise Temática. Trata-se de uma avaliação qualitativa que pressupõe a análise quantitativa dos resultados, possibilitando interpretar a comunicação de forma objetiva, sistemática e quantitativa do conteúdo manifesto nas entrevistas. É um instrumento que visa descrever, interpretar e compreender os dados, permitindo acessar os significados atribuídos aos sentimentos mais intensos e profundos vivenciados em dada situação. A unidade de análise é o discurso, o relato. 
Os dados quantitativos foram analisados através do programa estatístico SPSS for windows versão 16.0 .

Primeiramente, os pacientes foram divididos em dois grupos: curados bioquimicamente (calcitonina $<2 \mathrm{pg} / \mathrm{mL}$ ) pelo CMT e não curados (calcitonina $>2$ $\mathrm{pg} / \mathrm{mL}$ ), para verificar a influência da cura dos pacientes nos resultados das escalas.

A cura dos pacientes foi descrita, segundo cada característica qualitativa de interesse, com o uso de frequências absolutas e relativas e foi verificada a existência de associação na influência da cura com essas variáveis pelo uso de testes qui-quadrado ou testes exatos de Fisher ou testes da razão de verossimilhança (66), sendo os dois últimos aplicados quando a amostra é insuficiente para aplicação do teste qui-quadrado. As escalas avaliadas foram descritas, segundo a influência da cura, com uso de medidas resumo (média, desvio padrão, mediana, mínimo e máximo) e foram comparadas entre os grupos com uso de testes Mann-Whitney (66).

"Odds Ratio" foi estimado de cada variável de interesse relativamente à cura com os respectivos intervalos com 95\% de confiança com uso de regressões logísticas simples (67).

Foi estimado o modelo de regressão logística múltipla (68) para a cura, selecionando-se as variáveis que nos testes bivariados apresentaram níveis de significância inferiores a $0,20(\mathrm{p}<0,20)$ para avaliar conjuntamente a influência da cura nos resultados das variáveis das escalas.

Posteriormente, utilizando todos os pacientes, sem a divisão de grupos de curados e não curados foram calculadas as correlações de Spearman (67) entre as 
escalas de ansiedade, depressão e espírito de luta com as demais escalas para avaliar a existência de correlação entre as escalas.

Os testes foram realizados com nível de significância de 5\%.

\section{RESULTADOS}

Foram aplicados todos os protocolos psicológicos nos 43 pacientes com diagnóstico clínico e gênico de MEN2 de 12 famílias independentes (Tabela 1). A idade média dos pacientes no momento da aplicação dos protocolos era de 39,3 $\pm 14,7$ anos (19-70 anos). 


\subsection{Perfil demográfico e clínico:}

Os dados de distribuição demográfica dos 43 pacientes com MEN2, como estado civil, grau de instrução e atividades laborais no momento da aplicação dos protocolos são apresentados na tabela 4.

Tabela 4. Dados demográficos dos 43 pacientes com MEN2.

\section{Estado Civil, n (\%)}

\begin{tabular}{|cc|}
\hline Solteiro & $17(40)$ \\
\hline Casado & $24(56)$ \\
\hline Divorciado & $1(2)$ \\
\hline Viúvo & $1(2)$ \\
\hline $1^{\circ}$ Grau incompleto & Grau de Instrução, $\mathbf{n}(\%)$ \\
\hline $1^{\circ}$ Grau completo & $9(21)$ \\
\hline $2^{\circ}$ Grau incompleto & $4(9)$ \\
\hline $2^{\circ}$ Grau completo & $4(9)$ \\
\hline Superior incompleto & $9(21)$ \\
\hline Superior completo & $5(12)$ \\
\hline & $12(28)$ \\
\hline Trabalho ativo & Atividades laborais, $\mathbf{n}(\%)$ \\
\hline
\end{tabular}

n, número de pacientes

O perfil clínico e genético dos 43 pacientes com MEN2 foram obtidos através de revisão e análise dos prontuários. A prevalência de variantes fenotípicas e a frequência de cada uma das mutações germinativas RET nos 43 pacientes com MEN2 são apresentadas na tabela 5: 
Tabela 5. Prevalência de variantes fenotípicas e frequência de mutações germinativas RET nos 43 pacientes com MEN2.

\begin{tabular}{|cr|}
\hline & Tipos de MEN2, $\mathbf{n}(\%)$ \\
\hline MEN2A & $32(75)$ \\
\hline CMT Familial & $10(23)$ \\
\hline MEN2B & $1(2)$ \\
\hline Cys620Arg & Tipos de Mutação, n $(\%)$ \\
\hline Val804Met & $13(30)$ \\
\hline Met918Thr & $3(7)$ \\
\hline Cys634Arg & $1(2)$ \\
\hline Cys634Tyr & $9(21)$ \\
\hline Cys634Tyr, Tyr791Phe & $2(5)$ \\
\hline
\end{tabular}

Todos os 43 pacientes com MEN2 apresentavam CMT (100\%). No momento da avaliação psicológica, 41 pacientes tinham história de cirurgia para CMT. Os tipos de procedimentos cirúrgicos para tratamento de CMT, realizados nestes 41 pacientes, é apresentado na tabela 6 . Os outros dois pacientes aguardavam tratamento cirúrgico.

Ao todo, 19 pacientes apresentavam diagnóstico prévio ou atual de FEO (44\%; 19/43). Destes, 17 pacientes haviam sido previamente submetidos a procedimentos cirúrgicos para FEO: 13 por adrenalectomia bilateral sincrônica ou assincrônica e quatro por adrenalectomia unilateral. Havia outros dois pacientes com diagnóstico recente de FEO unilateral no momento da avaliação psicológica, que aguardavam cirurgia. Outro paciente, já operado por FEO unilateral, apresentava FEO em adrenal contralateral e, também, aguardava novo procedimento cirúrgico. Apenas um paciente tinha história de megacolon congênito e cirurgia corretiva na infância. 
Tabela 6. Tipos de procedimentos cirúrgicos conduzidos em 41 pacientes com MEN2 para tratamento de CMT e em 17 pacientes com FEO.

\begin{tabular}{|lc|}
\hline \multicolumn{2}{|c|}{ Tipos de Cirurgia, $\mathbf{n}(\%)$} \\
\hline Tireoidectomia Profilática & $1(2)$ \\
\hline Tireoidectomia Total & $2(5)$ \\
\hline Tireoidectomia Total +Esvaziamento Cervical & $38(88)$ \\
\hline Adrenalectomia unilateral & $4(9)$ \\
\hline $\begin{array}{l}\text { Adrenalectomia Bilateral (sincrônica ou } \\
\text { assincrônica) }\end{array}$ & $13(30)$ \\
\hline Megacolon Congênito & $1(2)$ \\
\hline
\end{tabular}

A idade média da primeira cirurgia de CMT foi de 27,8 $\pm 15,5$ (8-67) anos. Utilizando como critério de cura para CMT um valor sérico de calcitonina $<2 \mathrm{pg} / \mathrm{mL}$ encontramos uma taxa de cura de $33 \%$ (Figura 2). Desta forma, dois grupos de pacientes foram definidos, 16 pacientes com cura bioquímica (grupo 1) e outros 27 pacientes (grupo 2), sendo 25 já previamente operados por CMT e não curados com outros dois aguardando tratamento cirúrgico.

Ao todo, 41 pacientes tinham história de 59 procedimentos cirúrgicos relacionados à MEN2 (1,4 cirurgia/paciente; 1-6 cirurgias). 
Figura 2. Prevalência de pacientes com CMT curados e não curados.

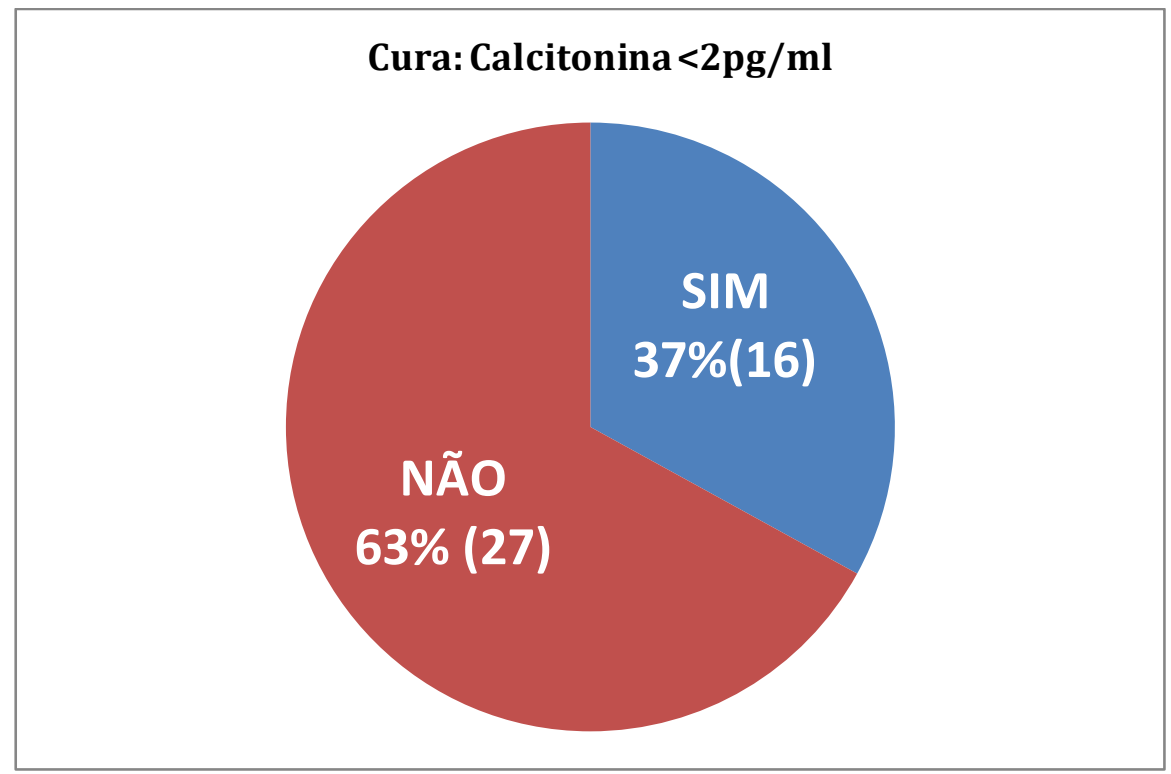

\subsection{Perfil psicológico:}

Em relação aos aspectos psicológicos dos pacientes com MEN2 encontramos os seguintes resultados de acordo com a entrevista semi-estruturada e os protocolos psicológicos:

A grande maioria dos 43 pacientes com MEN2 $(31 ; 72 \%)$ respondeu que teve medo de morrer ou ficou preocupada como reação à informação do diagnóstico de MEN2 (Tabela 7).

Vinte e oito pacientes com MEN2 tinham filhos (65\%). Dos 22 pais com filhos que tinham critérios clínicos para realização do teste genético, 21 (95\%) pais aceitaram fazer o exame de seus filhos. Apenas um dos filhos, já adulto, recusou se a submeter ao exame. Os outros seis pais não realizaram o exame genético de seus filhos por eles ainda não tinham alcançado a idade mínima recomendada para indicação do teste genético. 
Tabela 7. Reação ao diagnóstico de MEN2 e reação dos pais diante do resultado de RET positivo em seus filhos.

\begin{tabular}{|cc|}
\hline \multicolumn{2}{|c|}{ Reação ao diagnóstico de MEN2, n (\%) } \\
\hline Medo de Morrer & $20(46)$ \\
\hline Preocupado & $11(26)$ \\
Normal & $6(14)$ \\
\hline Era Criança & $6(14)$ \\
\hline Reação dos pais diante de $\boldsymbol{R E T}$ positivo de seus fillhos, $\mathbf{n}(\%)$ \\
\hline Muito Difícil (medo da perda) & $12(75)$ \\
\hline Surpresa & $4(25)$ \\
\hline Culpa diante do diagnóstico de $\boldsymbol{R} E \mathbf{T}$ positivo em seus fillhos, $\mathbf{n}(\%)$ \\
\hline Presença de culpa & $5(31)$ \\
\hline Ausência de culpa & $11(69)$
\end{tabular}

Ao todo, 16 pacientes com MEN2 dos 21 que submeteram os filhos ao teste genético, apresentaram filhos portadores de mutação germinativa RET. A reação dos 16 pais mediante o resultado do teste genético positivo em seus filhos bem como a presença ou ausência de culpa pela transmissão genética aos seus filhos são apresentadas na tabela 7 .

Em relação ao tratamento, 37 pacientes $(86 \%)$ relataram tomar todos os remédios prescritos pela equipe médica. Em relação à informação sobre a doença, 32 pacientes $(77 \%)$ responderam que se sentiam bem informados.

As frequências de sintomatologia ansiosa e depressiva encontradas pela escala HAD nos 43 pacientes com MEN2 são representadas na figura 3. Dezoito pacientes (42\%) apresentavam escore $\geq 8(11 \pm 2,93 ; 8$-18), compatível com presença de sintomatologia ansiosa, enquanto que foi ausente nos demais 25 pacientes com MEN2 
$(4 \pm 2,24 ; 0-7)$. No que se refere à avaliação de depressão, 11 pacientes $(26 \%)$ com MEN2 apresentavam escore $\geq 8(11 \pm 3,82 ; 8-20)$, compatível com presença de sintomatologia depressiva, enquanto que foi ausente em 32 (74\%) com valores médios de score $3 \pm 2,04(0-7)$.

Figura 3. Frequência de sintomatologia ansiosa e depressiva encontrada nos 43 pacientes com MEN2 usando a escala HAD

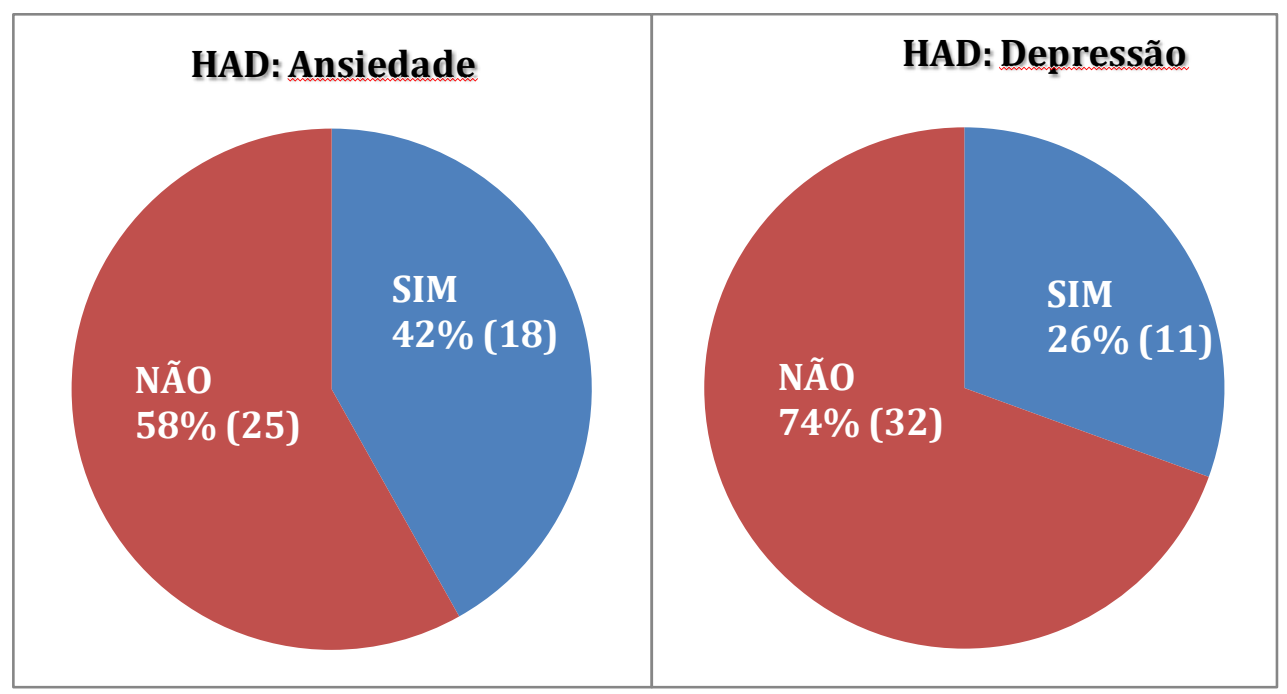

Os valores médios dos diferentes tipos de enfrentamento, obtidos pela aplicação do MINI-MAC, nos 43 pacientes diante do diagnóstico de MEN2 são apresentados na tabela 8. Os tipos de enfrentamento mais usados pelos pacientes diante do diagnóstico de MEN2 foram o espirito de luta, o evitamento cognitivo e o fatalismo. 
Tabela 8. Média \pm desvio padrão dos tipos de enfrentamento avaliados nos 43 pacientes diante do diagnóstico de MEN2 pelo MINI-MAC.

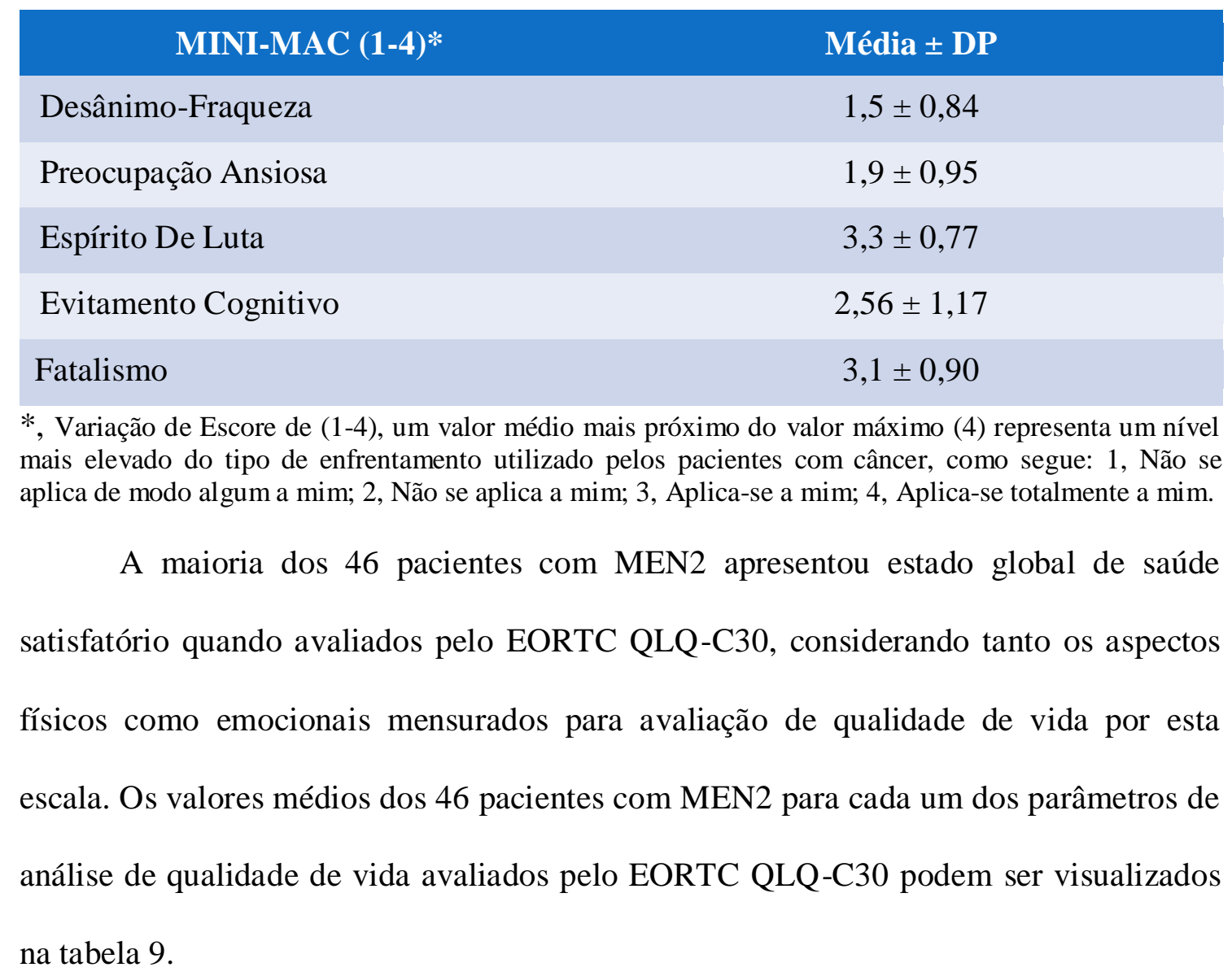


Tabela 9. Resultados obtidos da avaliação da qualidade de vida dos 46 pacientes com MEN2 usando EORTC QLQ-C30.

\section{Resultados EORTC QLQ-C30}

\section{Média \pm DP}

\section{Estado Global de Saúde/ QV*}

Desempenho de Atividades*

Funcionamento Cognitivo*

Dificuldades Financeiras*

Funcionamento Físico*

Funcionamento Emocional*

Funcionamento social*

Dor**

Fadiga**

Insônia**

Constipação**

Diarréia**

Náuseas e vômitos**

Dispnéia

Perda de apetite**
$68,1 \pm 22,3$

$72,4 \pm 32,2$

$57,7 \pm 36,1$

$17,4 \pm 30,5$

$79,3 \pm 21,2$

$59,7 \pm 32,8$

$81,4 \pm 28,9$

$35,3 \pm 36,6$

$31,3 \pm 29,5$

$27,8 \pm 35,9$

$23,6 \pm 36,7$

$12,7 \pm 20,7$

$12,2 \pm 21,2$

$27,3 \pm 35,7$

$$
19,7 \pm 35
$$

*, Variação do Score, de zero a 100, um escore mais elevado representa um nível mais elevado de função; *, Variação do Score de (0-100), um escore mais elevado representa um nível mais elevado de sintoma.

Para verificar a influência da cura da doença nos aspectos psicológicos analisados, os 43 pacientes foram divididos em dois grupos: curados bioquimicamente do CMT (16 pacientes, 33\%) e não curados (28 pacientes, 67\%). Os resultados obtidos podem ser visualizados nas tabelas 10,11 e 12 . 
Tabela 10. Descrição da cura dos pacientes segundo as características pessoais, do tumor, escalas de ansiedade e de depressão e resultado dos testes estatísticos bivariados.

\begin{tabular}{|c|c|c|c|c|c|c|c|}
\hline \multirow[b]{2}{*}{ Variável } & \multicolumn{2}{|c|}{ Cura } & \multirow[b]{2}{*}{ OR } & \multicolumn{2}{|c|}{ IC $(95 \%)$} & \multirow[b]{2}{*}{ Total } & \multirow[b]{2}{*}{$p$} \\
\hline & $\begin{array}{c}\text { Não } \\
(\mathbf{N}=27) \\
\end{array}$ & $\begin{array}{c}\text { Sim } \\
(N=16) \\
\end{array}$ & & Inferior & Superior & & \\
\hline \multicolumn{7}{|c|}{ Sexo } & 0,168 \\
\hline Feminino & $16(72,7)$ & $6(27,3)$ & 1,00 & & & 22 & \\
\hline Masculino & $11(52,4)$ & $10(47,6)$ & 2,42 & 0,68 & 8,64 & 21 & \\
\hline \multicolumn{3}{|c|}{ Idade (anos) } & 0,98 & 0,93 & 1,02 & & $0,334 £$ \\
\hline média (DP) & $41(16,2)$ & $36,4(11,5)$ & & & & $39,3(14,7)$ & \\
\hline $\begin{array}{c}\text { mediana } \\
\text { (mín.; máx.) }\end{array}$ & $37(19 ; 70)$ & $34,5(22 ; 65)$ & & & & $36(19 ; 70)$ & \\
\hline \multicolumn{7}{|c|}{ Trabalhando atualmente } & 0,054 \\
\hline Não & $13(81,2)$ & $3(18,8)$ & 1,00 & & & 16 & \\
\hline Sim & $14(51,9)$ & $13(48,1)$ & 4,02 & 0,93 & 17,41 & 27 & \\
\hline \multicolumn{7}{|c|}{ Reação em relação ao resultado dos filhos* } & $0,216^{* *}$ \\
\hline Medo de perda & $9(81,8)$ & $2(18,2)$ & 1,00 & & & 11 & \\
\hline Muito difícil & $0(0)$ & $1(100)$ & \# & & & 1 & \\
\hline Surpresa & $3(75)$ & $1(25)$ & 1,50 & 0,10 & 23,07 & 4 & \\
\hline \multicolumn{7}{|c|}{ Culpa* } & $0,245 \&$ \\
\hline Não & $7(63,6)$ & $4(36,4)$ & 1,00 & & & 11 & \\
\hline Sim & $5(100)$ & $0(0)$ & \# & & & 5 & \\
\hline \multicolumn{7}{|c|}{ Sentimento em ser portador de uma doença genética } & $0,724 * *$ \\
\hline $\begin{array}{l}\text { Medo de } \\
\text { morrer }\end{array}$ & $13(59,1)$ & $9(40,9)$ & 1,00 & & & 22 & \\
\hline $\begin{array}{c}\text { Normal/era } \\
\text { criança }\end{array}$ & $6(60)$ & $4(40)$ & 0,96 & 0,21 & 4,42 & 10 & \\
\hline $\begin{array}{l}\text { Preocupado } \\
\end{array}$ & $8(72,7)$ & $3(27,3)$ & 0,54 & 0,11 & 2,62 & 11 & \\
\hline \multicolumn{7}{|c|}{ Mutação } & $0,807 * *$ \\
\hline 634 & $16(61,5)$ & $10(38,5)$ & 1,00 & & & 26 & \\
\hline 791 & $8(61,5)$ & $5(38,5)$ & 1,00 & 0,25 & 3,93 & 13 & \\
\hline 804 & $2(66,7)$ & $1(33,3)$ & 0,80 & 0,06 & 10,01 & 3 & \\
\hline 918 & $1(100)$ & $0(0)$ & $\#$ & & & 1 & \\
\hline \multicolumn{7}{|c|}{ Ansiedade } & 0,655 \\
\hline Não & $15(60)$ & $10(40)$ & 1,00 & & & 25 & \\
\hline Sim & $12(66,7)$ & $6(33,3)$ & 0,75 & 0,21 & 2,66 & 18 & \\
\hline \multicolumn{7}{|c|}{ Depressão } & $0,278 \&$ \\
\hline Não & $22(68,8)$ & $10(31,2)$ & 1,00 & & & 32 & \\
\hline Sim & $5(45,5)$ & $6(54,5)$ & 2,64 & 0,65 & 10,73 & 11 & \\
\hline
\end{tabular}

* Não se aplica a todos os pacientes; ** Resultado do teste da razão de verossimilhanças; $\&$ Resultado do teste exato de Fisher; $£$ Resultado do teste t-Student; Resultado do teste qui-quadrado; \# Não é possível estimar. 
A Tabela 11 mostra que nenhuma das características avaliadas apresentou associação estatisticamente significativa com a cura dos pacientes $(\mathrm{p}>0,05)$, exceto para funcionamento físico ( $\mathrm{p}=0,021)$, que revelou um melhor status físico nos pacientes curados. A idade média dos pacientes era estatisticamente igual entre pacientes curados e não foram curados $(\mathrm{p}=0,334)$.

Tabela 11. Descrição das escalas segundo a influência da cura dos pacientes e resultado dos testes estatísticos bivariados.

\begin{tabular}{|c|c|c|c|c|c|c|c|}
\hline \multirow[b]{2}{*}{ Variável } & \multicolumn{2}{|c|}{ Cura } & \multirow[b]{2}{*}{ OR } & \multicolumn{2}{|c|}{ IC (95\%) } & \multirow[t]{2}{*}{ Total } & \multirow[t]{2}{*}{$p$} \\
\hline & $\begin{array}{c}\text { Não } \\
(\mathbf{N}=27)\end{array}$ & $\begin{array}{c}\text { Sim } \\
(\mathbf{N}=16)\end{array}$ & & Inferior & Superior & & \\
\hline $\begin{array}{l}\text { Desânimo- } \\
\text { Fraqueza }\end{array}$ & & & 1,37 & 0,67 & 2,81 & & 0,299 \\
\hline média (DP) & $1,4(0,7)$ & $1,6(1,1)$ & & & & $1,5(0,9)$ & \\
\hline $\begin{array}{c}\text { Mediana } \\
\text { (mín.; máx.) }\end{array}$ & $1(1 ; 4)$ & $1,1(1 ; 4)$ & & & & $1(1 ; 4)$ & \\
\hline $\begin{array}{l}\text { Preocupação } \\
\text { ansiosa }\end{array}$ & & & 1,00 & 0,52 & 1,93 & & 0,722 \\
\hline média (DP) & $1,9(0,9)$ & $1,9(1,1)$ & & & & $1,9(1)$ & \\
\hline $\begin{array}{c}\text { mediana } \\
\text { (mín.; máx.) }\end{array}$ & $2(1 ; 4)$ & $1,3(1 ; 4)$ & & & & $1,4(1 ; 4)$ & \\
\hline Espírito de luta & & & 0,83 & 0,33 & 2,10 & & 0,744 \\
\hline média (DP) & $3,4(0,5)$ & $3,3(0,9)$ & & & & $3,4(0,7)$ & \\
\hline $\begin{array}{c}\text { mediana } \\
\text { (mín.; máx.) }\end{array}$ & $3,3(2,3 ; 4)$ & $3,6(1 ; 4)$ & & & & $3,3(1 ; 4)$ & \\
\hline $\begin{array}{c}\text { Evitamento } \\
\text { cognitivo }\end{array}$ & & & 1,76 & 0,94 & 3,29 & & 0,082 \\
\hline média (DP) & $2,4(1,1)$ & $3(0,9)$ & & & & $2,6(1,1)$ & \\
\hline $\begin{array}{c}\text { mediana } \\
(\text { mín.; máx.) }\end{array}$ & $2(1 ; 4)$ & $3,1(1 ; 4)$ & & & & $2,5(1 ; 4)$ & \\
\hline Fatalismo & & & 0,61 & 0,28 & 1,36 & & 0,183 \\
\hline média (DP) & $3,3(0,8)$ & $3(0,8)$ & & & & $3,2(0,8)$ & \\
\hline $\begin{array}{c}\text { mediana } \\
\text { (mín.; máx.) }\end{array}$ & $3,4(2 ; 4)$ & $3,1(2 ; 4)$ & & & & $3,4(2 ; 4)$ & \\
\hline $\begin{array}{c}\text { Estado Global } \\
\text { de Saúde }\end{array}$ & & & 1,00 & 0,98 & 1,03 & & 0,684 \\
\hline média (DP) & $68,6(20,9)$ & $70,1(23,4)$ & & & & $69,1(21,6)$ & \\
\hline $\begin{array}{c}\text { mediana } \\
\text { (mín.; máx.) }\end{array}$ & $66,7(33,3 ; 100)$ & $66,7(0 ; 100)$ & & & & $66,7(0 ; 100)$ & \\
\hline $\begin{array}{c}\text { Desempenho de } \\
\text { atividades }\end{array}$ & & & 1,01 & 0,99 & 1,03 & & 0,310 \\
\hline média (DP) & $70,4(32,5)$ & $78,1(32,6)$ & & & & $73,3(32,4)$ & \\
\hline $\begin{array}{c}\text { Mediana } \\
\text { (mín.; máx.) }\end{array}$ & $83,3(0 ; 100)$ & $100(0 ; 100)$ & & & & $83,3(0 ; 100)$ & \\
\hline
\end{tabular}




\begin{tabular}{|c|c|c|c|c|c|c|c|}
\hline \multirow[b]{2}{*}{ Variável } & \multicolumn{2}{|c|}{ Cura } & \multirow[b]{2}{*}{ OR } & \multicolumn{2}{|c|}{ IC (95\%) } & \multirow[t]{2}{*}{ Total } & \multirow[t]{2}{*}{$p$} \\
\hline & $\begin{array}{c}\text { Não } \\
(\mathbf{N}=27)\end{array}$ & $\begin{array}{c}\text { Sim } \\
(\mathbf{N}=16)\end{array}$ & & Inferior & Superior & & \\
\hline $\begin{array}{c}\text { Funcionamento } \\
\text { cognitivo }\end{array}$ & & & 1,00 & 0,98 & 1,02 & & 0,888 \\
\hline média (DP) & $58,6(36,8)$ & $57,3(38)$ & & & & $58,1(36,8)$ & \\
\hline $\begin{array}{c}\text { Mediana } \\
\text { (mín.; máx.) }\end{array}$ & $\begin{array}{c}66,7 \\
(0 ; 100)\end{array}$ & $\begin{array}{c}66,7 \\
(0 ; 100)\end{array}$ & & & & $66,7(0 ; 100)$ & \\
\hline Fadiga & & & 1,00 & 0,97 & 1,02 & & 0,516 \\
\hline média (DP) & $32,9(29)$ & $28,5(33)$ & & & & $31,3(30,2)$ & \\
\hline $\begin{array}{c}\text { mediana } \\
\text { (mín.; máx.) }\end{array}$ & $22,2(0 ; 100)$ & $22,2(0 ; 88,9)$ & & & & $22,2(0 ; 100)$ & \\
\hline Dor & & & 1,00 & 0,98 & 1,02 & & 0,833 \\
\hline média (DP) & $35,8(36)$ & $34,4(41)$ & & & & $35,3(37,5)$ & \\
\hline $\begin{array}{c}\text { Mediana } \\
\text { (mín.; máx.) }\end{array}$ & $33,3(0 ; 100)$ & $8,3(0 ; 100)$ & & & & $33,3(0 ; 100)$ & \\
\hline Insonia & & & 1,00 & 0,98 & 1,02 & & 0,933 \\
\hline média (DP) & $28,4(37,8)$ & $26,3(36,1)$ & & & & $27,6(36,8)$ & \\
\hline $\begin{array}{c}\text { Mediana } \\
\text { (mín.; máx.) }\end{array}$ & $0(0 ; 100)$ & $0(0 ; 100)$ & & & & $0(0 ; 100)$ & \\
\hline $\begin{array}{c}\text { EORTC } \\
\text { QLQ-C30 } \\
\end{array}$ & & & 1,00 & 0,98 & 1,01 & & 0,624 \\
\hline média (DP) & $25,9(39,6)$ & $18,7(34,4)$ & & & & $23,3(37,5)$ & \\
\hline $\begin{array}{c}\text { Mediana } \\
\text { (mín.; máx.) }\end{array}$ & $0(0 ; 100)$ & $0(0 ; 100)$ & & & & $0(0 ; 100)$ & \\
\hline $\begin{array}{l}\text { Dificuldades } \\
\text { financeiras }\end{array}$ & & & 1,00 & 0,98 & 1,02 & & 0,934 \\
\hline média (DP) & $16,1(29,8)$ & $18,8(34,4)$ & & & & $17,1(31,2)$ & \\
\hline $\begin{array}{c}\text { Mediana } \\
\text { (mín.; máx.) }\end{array}$ & $0(0 ; 100)$ & $0(0 ; 100)$ & & & & $0(0 ; 100)$ & \\
\hline $\begin{array}{c}\text { Funcionamento } \\
\text { físico } \\
\end{array}$ & & & 1,03 & 0,99 & 1,07 & & 0,021 \\
\hline média (DP) & $76,8(18,2)$ & $87,1(20,7)$ & & & & $80,6(19,6)$ & \\
\hline $\begin{array}{c}\text { Mediana } \\
\text { (mín.; máx.) } \\
\end{array}$ & $80(33,3 ; 100)$ & $100(40 ; 100)$ & & & & $86,7(33 ; 100)$ & \\
\hline $\begin{array}{c}\begin{array}{c}\text { Funcionamento } \\
\text { emocional }\end{array} \\
\end{array}$ & & & 1,00 & 0,98 & 1,01 & & 0,677 \\
\hline média (DP) & $62,1(33,5)$ & $57,3(33,9)$ & & & & $60,3(33,3)$ & \\
\hline $\begin{array}{c}\text { mediana } \\
(\text { mín.; máx.) } \\
\end{array}$ & $75(0 ; 100)$ & $66,7(0 ; 100)$ & & & & $66,7(0 ; 100)$ & \\
\hline $\begin{array}{c}\begin{array}{c}\text { Funcionamento } \\
\text { social }\end{array} \\
\end{array}$ & & & 1,02 & 0,99 & 1,05 & & 0,214 \\
\hline média (DP) & $77,9(32,4)$ & $90,6(18,2)$ & & & & $82,6(28,4)$ & \\
\hline $\begin{array}{c}\text { mediana } \\
\text { (mín.; máx.) }\end{array}$ & $100(0 ; 100)$ & $100(50 ; 100)$ & & & & $100(0 ; 100)$ & \\
\hline Náusea e vômito & & & 0,99 & 0,96 & 1,03 & & 0,678 \\
\hline média (DP) & $13(22,8)$ & $10,4(20,1)$ & & & & $12(21,6)$ & \\
\hline $\begin{array}{c}\text { Mediana } \\
\text { (mín.; máx.) } \\
\end{array}$ & $0(0 ; 100)$ & $0(0 ; 66,7)$ & & & & $0(0 ; 100)$ & \\
\hline Dispnéia & & & 1,00 & 0,98 & 1,02 & & 0,910 \\
\hline média (DP) & $28,4(37,8)$ & $25(35,5)$ & & & & $27,1(36,6)$ & \\
\hline $\begin{array}{c}\text { mediana } \\
\text { (mín.; máx.) }\end{array}$ & $0(0 ; 100)$ & $0(0 ; 100)$ & & & & $0(0 ; 100)$ & \\
\hline
\end{tabular}




\begin{tabular}{|c|c|c|c|c|c|c|c|}
\hline \multirow[b]{2}{*}{ Variável } & \multicolumn{2}{|c|}{ Cura } & \multirow[b]{2}{*}{ OR } & \multicolumn{2}{|c|}{ IC (95\%) } & \multirow[t]{2}{*}{ Total } & \multirow[t]{2}{*}{$p$} \\
\hline & $\begin{array}{c}\text { Não } \\
(\mathbf{N}=\mathbf{2 7})\end{array}$ & $\begin{array}{c}\text { Sim } \\
(\mathbf{N}=16)\end{array}$ & & Inferior & Superior & & \\
\hline Perda de apetite & & & 1,00 & 0,99 & 1,02 & & 0,750 \\
\hline média (DP) & $18,5(36,2)$ & $20,8(36,3)$ & & & & $19,4(35,8)$ & \\
\hline $\begin{array}{c}\text { Mediana } \\
\text { (mín.; máx.) } \\
\end{array}$ & $0(0 ; 100)$ & $0(0 ; 100)$ & & & & $0(0 ; 100)$ & \\
\hline Diarréia & & & 1,00 & 0,98 & 1,02 & & 0,846 \\
\hline média (DP) & $12,4(26,4)$ & $12,5(29,5)$ & & & & $12,4(27,2)$ & \\
\hline $\begin{array}{c}\text { mediana } \\
\text { (mín.; máx.) }\end{array}$ & $0(0 ; 100)$ & $0(0 ; 100)$ & & & & $0(0 ; 100)$ & \\
\hline
\end{tabular}

Tabela 12. Resultado da regressão logística múltipla para explicar a influência da cura dos pacientes segundo características e escalas avaliadas.

\begin{tabular}{|c|c|c|c|c|}
\hline \multirow{2}{*}{ Variável } & OR & \multicolumn{2}{|c|}{ IC (95\%) } \\
\hline $\begin{array}{c}\text { Evitamento } \\
\text { cognitivo }\end{array}$ & 2,29 & 1,12 & Superior & $p$ \\
\hline $\begin{array}{c}\text { Funcionamento } \\
\text { físico }\end{array}$ & 1,05 & 1,00 & 4,69 & $\mathbf{0 , 0 2 4}$ \\
\hline
\end{tabular}

Pela Tabela 12, após aplicação de regressão logística, tem-se que a cura dos pacientes influenciou estatisticamente o resultado do evitamento cognitivo e do funcionamento físico dos pacientes, sendo que nos pacientes curados houve um aumento de $129 \%$ a cada aumento de um ponto na escala de evitamento cognitivo e aumentou $5 \%$ a cada aumento de um ponto na escala de funcionamento físico $(0,021)$, sendo esta escala maior nos pacientes que foram curados. 
Tabela 13. Resultado das correlações positiva das escalas de ansiedade, depressão e espírito de luta com as demais escalas:

\begin{tabular}{|c|c|c|c|c|}
\hline \multicolumn{2}{|l|}{ Correlação } & \multirow{2}{*}{$\begin{array}{c}\text { HAD: Ansiedade } \\
\qquad 0,702\end{array}$} & \multirow[t]{2}{*}{ HAD: Depressão } & \multirow[t]{2}{*}{ Espírito de luta } \\
\hline & $\mathrm{r}$ & & & \\
\hline 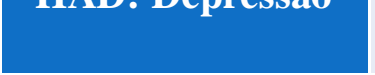 & $\mathrm{p}$ & $<0,001$ & & \\
\hline \multirow{2}{*}{ Espírito de luta } & $\mathrm{r}$ & 0,023 & $-0,151$ & \\
\hline & $\mathrm{p}$ & 0,882 & 0,334 & \\
\hline \multirow{2}{*}{ Desânimo-Fraqueza } & $\mathrm{r}$ & 0,662 & 0,612 & 0,117 \\
\hline & $\mathrm{p}$ & $<0,001$ & $<0,001$ & 0,453 \\
\hline \multirow{2}{*}{$\begin{array}{c}\text { Preocupação } \\
\text { ansiosa }\end{array}$} & $\mathrm{r}$ & 0,819 & 0,678 & 0,003 \\
\hline & $\mathrm{p}$ & $<0,001$ & $<0,001$ & 0,986 \\
\hline \multirow{2}{*}{$\begin{array}{c}\text { Evitamento } \\
\text { cognitivo }\end{array}$} & $\mathrm{r}$ & 0,567 & 0,470 & 0,226 \\
\hline & $\mathrm{p}$ & $<0,001$ & 0,001 & 0,144 \\
\hline \multirow{2}{*}{ Fadiga } & $\mathrm{r}$ & 0,610 & 0,570 & 0,000 \\
\hline & $\mathrm{p}$ & $<0,001$ & $<0,001$ & 0,999 \\
\hline \multirow{2}{*}{ Dor } & $\mathrm{r}$ & 0,598 & 0,593 & 0,069 \\
\hline & $\mathrm{p}$ & $<0,001$ & $<0,001$ & 0,658 \\
\hline \multirow{2}{*}{ Insônia } & $\mathrm{r}$ & 0,385 & 0,256 & 0,220 \\
\hline & $\mathrm{p}$ & 0,011 & 0,097 & 0,156 \\
\hline \multirow{2}{*}{ Constipação } & $\mathrm{r}$ & 0,345 & 0,424 & $-0,049$ \\
\hline & $\mathrm{p}$ & $\mathbf{0 , 0 2 3}$ & 0,005 & 0,754 \\
\hline
\end{tabular}


Tabela 14. Resultado das correlações negativas das escalas de ansiedade, depressão e espírito de luta com as demais escalas:

\begin{tabular}{|c|c|c|c|c|}
\hline \multicolumn{2}{|l|}{ Correlação } & \multirow{2}{*}{$\begin{array}{l}\text { HAD: Ansiedade } \\
-0,528\end{array}$} & \multirow{2}{*}{$\begin{array}{c}\text { HAD: Depressão } \\
-0,553\end{array}$} & \multirow{2}{*}{$\begin{array}{c}\text { Espírito de luta } \\
0,003\end{array}$} \\
\hline & $\mathrm{r}$ & & & \\
\hline saude & $\mathrm{p}$ & $<0,001$ & $<0,001$ & 0,985 \\
\hline \multirow{2}{*}{$\begin{array}{c}\text { Desempenho de } \\
\text { atividades }\end{array}$} & $\mathrm{r}$ & $-0,733$ & $-0,618$ & 0,043 \\
\hline & $\mathrm{p}$ & $<0,001$ & $<0,001$ & 0,785 \\
\hline \multirow{2}{*}{$\begin{array}{l}\text { Funcionamento } \\
\text { cognitivo }\end{array}$} & $\mathrm{r}$ & $-0,632$ & $-0,543$ & $-0,002$ \\
\hline & $\mathrm{p}$ & $<0,001$ & $<0,001$ & 0,988 \\
\hline \multirow{2}{*}{$\begin{array}{c}\text { Funcionamento } \\
\text { físico }\end{array}$} & $\mathrm{r}$ & $-0,376$ & $-0,297$ & $-0,298$ \\
\hline & $\mathrm{p}$ & 0,013 & 0,053 & 0,052 \\
\hline \multirow{2}{*}{$\begin{array}{l}\text { Funcionamento } \\
\text { emocional }\end{array}$} & $\mathrm{r}$ & $-0,769$ & $-0,667$ & 0,006 \\
\hline & $\mathrm{p}$ & $<0,001$ & $<0,001$ & 0,970 \\
\hline $\begin{array}{c}\text { Funcionamento } \\
\text { social }\end{array}$ & $\mathrm{r}$ & $-0,341$ & $-0,288$ & $-0,053$ \\
\hline
\end{tabular}

A Tabela 13 mostra que há correlação direta estatisticamente significativa entre ansiedade e depressão $(r=0,702 ; p<0,001)$, mas não há correlação estatisticamente significativa da ansiedade e depressão com o espírito de luta $(\mathrm{p}>0,05)$. O espírito de luta apresentou correlação direta estatisticamente significativa com fatalismo $(r=0,369$; $\mathrm{p}=0,015)$. Já ansiedade e depressão apresentaram correlações estatisticamente significativas com praticamente as mesmas escalas, uma vez que houve correlação 
direta entre elas, sendo as correlações da ansiedade com as demais escalas quase sempre superiores a da depressão com as demais escalas. Foram observadas correlações diretas estatisticamente significativas com desânimo-fraqueza, preocupação ansiosa, evitamento cognitivo, fadiga, dor, insônia, náusea e vômito, dispnéia, perda de apetite e diarreia, algumas apenas com ansiedade, ou seja, quanto maior as escalas de ansiedade ou depressão, maiores são os valores das escalas citadas, como mostra a tabela 4. Enquanto que as escalas de estado global de saúde, desempenho de atividades, funcionamento cognitivo e funcionamento emocional apresentaram correlações inversas estatisticamente significativas com ansiedade e depressão ( $\mathrm{p}<0,05)$, ou seja, quanto maiores os valores das escalas de ansiedade e depressão, menores os valores das escalas listadas, como mostra a tabela 14.

\subsection{Resultados segundo uma análise descritiva}

Para uma compreensão qualitativa do perfil psicológico dos pacientes com MEN2, vamos analisar a pergunta 14 da entrevista semi-dirigida, colocando a resposta dos pacientes em sua integridade.

“Como é para você ser portador de uma doença genética?"

1- "O lado ruim disto é ter que estar vindo ao médico, risco de recidiva, dispor de muito tempo para fazer exames. Preocupa-me um pouco, o fato dos filhos terem $50 \%$ de herança".

2- "Muito ruim. Eu me sinto mal, levar uma doença para o resto da vida, tomar remédios, fazer inúmeras cirurgias, transmitir geneticamente. É muito difícil encarar a doença". 
3- "Fico preocupada, tenho filhos, tenho medo de ter infarto, derrame e medo de morrer e deixar os filhos, fico muito irritada, descontrole total".

4- "Me deixa angustiada e preocupada, o fato dos filhos poderem herdar a doença e sofrer as consequências dela”.

5- "Não tem o que fazer, tem que aceitar e pronto".

6- "Sinto que é difícil, pela possibilidade de herança dos filhos, minha esposa quer ter outro filho, penso, se terei por causa da possibilidade grande de herança”.

7- “É terrível, é um absurdo, me sinto um lixo, um depósito de doença. Vi minha família inteira, todos os meus filhos com a doença, vi vários familiares morrerem. Isto me deixa extremamente angustiada".

8- "É difícil pela possibilidade de herança genética dos filhos. Já penso que meus filhos não terão nada, pois, tenho uma crença evangélica, que Deus não permitirá (paciente está esperando o $1^{\circ}$ filho, 3 meses de gestação)".

9- "Não culpo ninguém, nem me culpo, por ser hereditário. Não tenho tantas preocupações, pois, decidi que não terei filhos”.

10- "Não penso nisto, é como se não tivesse a doença".

11-“Tenho muita preocupação, pois os filhos e os netos poderão ter. É muito difícil de aceitar".

12- "É muito difícil pensar na possibilidade do DNA do meu filho ser positivo".

13- "Eu não teria filhos se soubesse que transmitiria a doença para os meus filhos". 


\section{5- DISCUSSÃO}

A descoberta de um câncer pode ser representada como um evento ameaçador. Considerando um câncer hereditário, além do medo diário de perda de autonomia, da limitação de atividades, da perda de controle da doença, de procedimentos cirúrgicos ou de tratamentos oncológicos, convive-se com a possibilidade de transmissão aos descendentes (16). Em relação à MEN2, a doença avaliada neste estudo, este risco é considerado muito elevado (50\%) (8-18).

A importância deste trabalho pode ser demonstrada no número reduzido de pesquisas enfocando os aspectos psicológicos em pacientes com MEN2. Assim, em uma revisão da literatura, quatro estudos foram encontrados, desenvolvidos por um grupo de pesquisadores holandeses da Universidade de Ultrech que possuem larga experiência no manejo clínico de neoplasias endócrinas múltiplas coordenado pelo Professor C. Lips. $(49,50,51,16)$. Nestes trabalhos foi abordado principalmente os aspectos psicológicos dos pais em relação aos resultados dos testes genéticos dos filhos e o manejo na realização do aconselhamento genético das famílias afetadas. O presente estudo é o primeiro a utilizar escalas padronizadas para avaliação de ansiedade, depressão, qualidade de vida e coping e a desenvolver um protocolo específico direcionado para avaliação do perfil psicológico dos pacientes com MEN2.

Como se pode verificar dos resultados apresentados, os pacientes ao receberem o diagnóstico, tiveram muito medo de morrer ou de perder seus filhos. A angústia e expectativa em relação ao resultado dos testes genéticos dos seus filhos ou parentes, aos procedimentos cirúrgicos a serem realizados ou possíveis tratamentos, riscos de recidiva da doença, possivelmente está relacionado a um alto índice de sintomatologia ansiosa 
apresentada no estudo (46\%), que representa um índice consideravelmente maior do que na população geral (20\%) (32).

O CMT, presente em praticamente $100 \%$ dos pacientes com MEN2 é considerado um câncer de crescimento lento (10-18), o que leva os pacientes a conviverem com o estigma da doença muitas vezes por anos, exacerbando, a presença da ansiedade e expectativa diária em relação ao processo de adoecimento. Este fato pode ter justificado o evitamento cognitivo como um dos tipos de enfrentamento mais utilizados pelos pacientes com MEN2. Não pensar na doença os ajudam nesta angústia de convivência, por uma vida inteira, muitas vezes, com uma doença ameaçadora, que pode progredir a qualquer momento.

A representação da doença ameaçadora pode ser ratificada na resposta dos pacientes à pergunta: “Como é para você ser portador de uma doença genética?” Os pacientes expressaram sentimentos como se sentirem "um deposito de doença", "angústia em relação a ter ou não filhos devido ao risco de transmissão", "convivência com muitos exames, procedimentos cirúrgicos e uso de medicamentos contínuos pela vida toda".

O índice de sintomatologia depressiva encontrado nos pacientes avaliados (25\%), também consideravelmente maior do que o da população geral (3\%, chegando a $10 \%$ em pacientes que fazem tratamento em algum serviço de saúde) (32), mostra que deve-se ter um olhar mais cuidadoso em relação aos aspectos psicológicos em pacientes com MEN2. A depressão neste tipo de paciente pode levá-los desde a não adesão ao tratamento até vivenciarem uma exacerbação das angústias em resposta ao doloroso processo do tratamento oncológico. As implicações e incertezas deste diagnóstico 
podem intensificar emoções. O choque ou descrença encontrada na descoberta do tumor pode se associar com sintomas como ansiedade, tristeza, irritabilidade, perda do sono e distúrbios do apetite. Em geral, os pacientes oncológicos expressam vários medos que incluem: medo da inabilidade, da perda prévia de posição ou função ocupada; dependência ou perda do controle além de medo de perder a vontade de viver. Alguns pacientes se preocupam com o fato que suas vivências em relação ao adoecimento irão se tornar intoleráveis, que poderão ser abandonados pelos outros e temem antecipar o curso da sua morte (31).

A elevada prevalência de depressão e de ansiedade encontrada nos pacientes com MEN2 são fortalecidas pela análise estatística, que demonstrou forte correlação entre as escalas de ansiedade e depressão com as sub-escalas: preocupação ansiosa, desamparo desesperança, evitamento cognitivo, fadiga, dor, insônia, constipação, funcionamento emocional, funcionamento cognitivo, funcionamento físico, desempenho de atividades, que podem ser considerados sintomatologia em relação ao diagnóstico de depressão e ansiedade.

A aplicação do protocolo de pesquisa aqui descrito possibilitou o diagnóstico de 11 pacientes $(25 \%)$ que necessitaram de acompanhamento psicológico psicoterápico individual. Estes pacientes foram seguidos por no mínimo 6 meses, em sessões semanais de 50 minutos. Através deste acompanhamento mais profundo, pôde-se além de trabalhar as questões em relação à readaptação na convivência com um câncer hereditário, ter mais subsídios para um trabalho, juntamente com a equipe médica, no aperfeiçoamento do aconselhamento genético. Motta (54) enfatiza que o trabalho do psicólogo com pacientes com neoplasias genéticas não se esgota com a explicação da 
causa da doença e de seu risco de recorrência ou ocorrência. Acredita-se que seja necessária a execução de um processo assistencial, com entrevistas e sessões terapêuticas, para tratar toda a problemática associada à ansiedade, culpa, depressão, fantasias e outras manifestações mórbidas do psiquismo do paciente com diagnóstico de doenças genéticas, modelo que foi utilizado no trabalho assistencial com estes pacientes.

Foi realizado acompanhamento nas consultas médicas de todos os pacientes do ambulatório de MEN2 durante 3 anos, nas reuniões clínicas de discussão de casos, nas visitas médicas na enfermaria e na internação de pacientes para realização de exames para estadiamento e/ou tratamento da doença. Foi, também, conduzida a preparação psicológica tanto no período pré- como no pós-cirúrgico de todos os sete pacientes operados pelo Serviço. Isto propiciou um trabalho multidisciplinar, envolvendo médicos e psicólogo, no acompanhamento destas 12 famílias resultando na obtenção de dados do perfil clínico e psicológico destes pacientes. Esta abordagem multidisciplinar contínua possibilitou um aperfeiçoamento do aconselhamento genético dos pacientes com MEN2.

A maioria dos pacientes se sentiam bem informados pela equipe médica em relação à doença, o que pode ter contribuído tanto para a forte adesão ao tratamento médico como também ao consentimento para a realização dos testes genéticos de seus filhos sob risco de doença ( $95 \%)$. Os profissionais de saúde, ao fornecerem informações sobre a doença, tratamentos e efeitos secundários ajudam a integração e colaboração dos doentes nos cuidados de saúde, permitindo que façam parte do tratamento. A 
informação funciona como catalisadora, permitindo aos doentes e famílias se adaptarem mais facilmente à doença e se sentirem menos ameaçados (58).

Diante do sofrimento psíquico representado pelo diagnóstico de MEN2 e todo seu processo de adoecimento, podemos verificar a importância de um trabalho multidisciplinar constituído por médicos e psicólogos no acompanhamento destes pacientes. O psicólogo pode ter um papel importante no acompanhamento das famílias portadoras de MEN2 e o seu trabalho pode ter como atividades prioritárias os seguintes aspectos: a compreensão de aspectos médicos que permitam esclarecer aos pacientes, através do uso de uma abordagem psicológica, dúvidas sobre o diagnóstico, a causa provável do transtorno, seus mecanismos de herança e os possíveis tratamentos a serem realizados; a verificação da adesão ao tratamento médico de indivíduos portadores de mutação ou afetados; a orientação dos portadores quanto aos riscos de gerarem descendentes afetados geneticamente e as implicações psicológicas deste fato do ponto de vista de todos os envolvidos. Estas ações visam o ajustamento pessoal e/ou profissional bem como o atendimento e acompanhamento psicológico do paciente portador de doença genética e de seus familiares $(54,58)$. Este acompanhamento pode levar os pacientes e todos os familiares envolvidos a um processo de readaptação na convivência de ser portador de um câncer hereditário e as implicações da doença em sua vida, trabalhando o paciente de forma biopsicossocial, visando seu bem estar completo e colaborando também na adesão ao tratamento médico. 


\section{6- CONCLUSÕES}

- Pela elevada prevalência nos resultados apresentados, tanto a sintomatologia ansiosa como a depressiva devem ser ativamente investigadas em pacientes com MEN2. - Uma correlação positiva e estatisticamente significativa foi observada entre depressão e ansiedade e com as sub-escalas: desânimo-fraqueza, preocupação ansiosa, evitamento cognitivo, fadiga, dor, insônia, náusea e vômito, dispnéia, perda de apetite e diarréia.

- E uma associação inversa com as sub-escalas: estado global de saúde, desempenho de atividades, funcionamento cognitivo e funcionamento emocional.

- $\quad$ O impacto de ser portador de uma doença genética predispondo a câncer gerou nos pacientes com MEN2 medo de morte e de perda dos filhos.

- $\mathrm{O}$ evitamento cognitivo, fatalismo e forte espirito de luta foram utilizados como formas de enfrentamento da doença (coping).

- O aconselhamento genético propiciou uma excelente adesão tanto para realização de testes genéticos dos filhos como para o tratamento clínico da doença.

- O protocolo de avaliação psicológica desenvolvido e direcionado ao atendimento de pacientes com MEN2 mostrou-se eficiente na identificação de indivíduos com necessidade de assistência psicológica, incluindo acompanhamento psicoterápico individual em $25 \%$ dos pacientes.

Entende-se que este projeto poderá propiciar o início do desenvolvimento de um ambulatório multidisciplinar envolvendo tanto médicos como psicólogos com manejo em aconselhamento genético e também no desenvolvimento de novas pesquisas no estudo dos aspectos psicológicos em pacientes com MEN2. 


\section{7- REFERENCIAS BIBLIOGRÁFICAS}

1. Sipple JH. The association of pheochromocytoma with carcinoma of the thyroid gland. Am J Med 31:163-166, 1961.

2. Cushman, P. Jr. Familial endocrine tumors; report of two unrelated kindred affected with pheochromocytomas, one also with multiple thyroid carcinomas. Am. J. Med. 32, 352-360 (1962).

3. Steiner, A. L., Goodman, A. D. \& Powers, S. R. Study of a kindred with pheochromocytoma, medullary thyroid carcinoma, hyperparathyroidism and Cushing's disease: multiple endocrine neoplasia, type 2. Medicine (Baltimore) 47, 371-409 (1968).

4. Takahashi, M., Ritz, J. \& Cooper, G. M. Activation of a novel human transforming gene, ret, by DNA rearrangement. Cell 42, 581-588 (1985).

5. Simpson, N. E. \& Kidd, K. K. Where is the locus for multiple endocrine neoplasia type 2A? Henry Ford Hosp. Med. J. 35, 168-171 (1987).

6. Mathew, C. G. et al. A linked genetic marker for multiple endocrine neoplasia type 2A on chromosome 10. Nature 328, 527-528 (1987).

7. Ishizaka $\mathrm{Y}$, Itoh $\mathrm{F}$, Tahira $\mathrm{T}$, et al. Human ret proto-oncogene mapped to chromosome 10q11.2. Oncogene. 1989;4:1519-1521.

8. Donis-Keller H, Dou S, Chi D, Carlson KM, Toshima K, Lairmore TC, et al. Mutations in the RET proto-oncogene are associated with MEN 2A and FMTC. Hum Mol Genet 2: 851-6, 1993.

9. Mulligan LM, Kwok JB, Healey CS, Elsdon MJ, Eng C, Gardner E, et al. Germ-line mutations of the RET proto-oncogene in multiple endocrine neoplasia type 2A. Nature 363: 458-60, 1993.

10. Eng C, Clayton D, Schuffenecker I, Lenoir G, Cote G, Gagel RF, et al. The relationship between specific RET proto-oncogene mutations and disease phenotype in multiple endocrine neoplasia type 2 . International RET mutation consortium analysis. JAMA. 1996;276(19):1575-9.

11. Brandi ML, Gagel RF, Angeli A, Bilezikian JP, Beck-Peccoz P, Bordi C, et al. Guidelines for diagnosis and therapy of MEN type 1 and type 2. J Clin Endocrinol Metab. 2001;86(12):5658-71. 
12. Carling T. Multiple endocrine neoplasia syndrome: genetic basis for clinical management. Curr Opin Oncol. 2005;17(1):7-12.

13. Toledo SP, dos Santos MA, Toledo RA, Lourenço DM Jr. Impact of RET protooncogene analysis on the clinical management of multiple endocrine neoplasia type 2 . Clinics (Sao Paulo). 2006 Feb;61(1):59-70.

14. Santos MA, Nunes AB, Abelin N, Ezabella MC, Toledo Rde A, Lourenço D M Jr, Hayashida CY, Fonseca II, Toledo SP. Genetic screening of multiple endocrine neoplasia type 2: experience of the USP Endocrine Genetics Unit. Arq Bras Endocrinol Metabol. 2006;50(1):7-16.

15. Kloos RT, Eng C, Evans DB, Francis GL, Gagel RF, Gharib H, et al. Medullary thyroid cancer: management guidelines of the American Thyroid Association. Thyroid. 2009;19(6):565-612.

16. Lips CJ, Höppener JW, Van Nesselrooij BP, Van der Luijt RB. Counselling in multiple endocrine neoplasia syndromes: from individual experience to general guidelines. J Intern Med. 2005;257(1):69-77.

17. Waguespack SG, Rich TA, Perrier ND, Jimenez C, Cote GJ. Management of medullary thyroid carcinoma and MEN2 syndromes in childhood. Nat. Rev. Endocrinol. 2011;7:596-607

18. Wells SA Jr, Pacini F, Robinso BG, et al. Multiple Endocrine Neoplasia Type 2 and Familial Medullary Thyroid Carcinoma: An Update. J Clin Endocrinol Metab. 2013;98:3149-64.

19. Toledo RA, Wagner SM, Coutinho FL, Lourenço DM Jr, Azevedo JA, Longuini $\mathrm{VC}$, et al. High penetrance of pheochromocytoma associated with the novel C634Y/Y791F double germline mutation in the RET protooncogene. J Clin Endocrinol Metab. 2010;95(3):1318-27.

20. Dos Santos MACG, De Quedas EPS, Toledo RDA, Lourenço Jr. DM, De Toledo SPA. Screening of RET gene mutations in multiple endocrine neoplasia type-2 using conformation sensitive gel electrophoresis (CSGE). Arq Bras Endocrinol Metabol 2007;51(9):1468-76.

21. Toledo SPA, Lourenço Jr. DM, Santos MA, Tavares MR, Toledo RA, CorreiaDeurI JEM. Hypercalcitoninemia is not pathognomonic of medullary thyroid carcinoma. Clinics 2009;64(7):699-706.

22. Correia-Deur JEM, Toledo RA, Imazawa AT, Lourenço Jr. DM, Ezabella MCL, Tavares MR, Toledo SPA. Sporadic medullary thyroid carcinoma: Clinical data from a university hospital. Clinics 2009;64(5):379-86. 
23. Toledo RA, Sekiya T, Longuini VC, Coutinho FL, Lourenço Jr. DM, Toledo SPA. Narrowing the gap of personalized medicine in emerging countries: The case of multiple endocrine neoplasias in Brazil. Clinics 2012;67 (SUPPLEMENT):3-6

24. Complete Resolution of Hypercortisolism with Sorafenib in a Patient with Advanced Medullary Thyroid Carcinoma and Ectopic ACTH (Adrenocorticotropic Hormone) Syndrome Thyroid 2014;24(6):1062-6.

25. Frank-Raue K, Rybicki LA, Erlic Z, Schweizer H, Winter A, Milos I, et al. Risk profiles and penetrance estimations in multiple endocrine neoplasia type $2 \mathrm{~A}$ caused by germline RET mutations located in exon 10. Hum Mutat. 2011;32(1):51-8.

26. Folkman S, Lazarus RS. An analysis of coping in a middle-aged community sample. J Health Soc Behav. 1980;21(3):219-39.

27. Watson M, Greer S, Young J, Inayat Q, Burgess C, Robertson B. Development of a questionnaire measure of adjustment to cancer: the MAC scale. Psychol Med. 1988;18(1):203-9.

28. Watson M. The Mini-MAC: Further Development of the Adjustment to Cancer Scale. In: Law M, editor. 3 ed. Journal of Psychosocial Oncology 1994. p. 33-46.

29. Schnoll RA. Spirituality, demografic and disease factors, and ajustment to cancer. In: Harlow LL, editor. Cancer Pract 2000. p. 298-304.

30. Carvalho N.S. Asma e doença pulmonar obstrutiva crônica: In: Ribeiro PS, editor. Uma comparação entre variáveis de ansiedade e depressão. Jornal Brasileiro de Pneumologia, 2007. p. 1-6.

31. Kubler-Ross E. Sobre a morte e o morrer: o que os doentes terminais têm para ensinar a médicos, enfermeiras, religiosos e aos seus próprios parentes. São Paulo: Martins Fontes,: $8^{\mathrm{a}}$ ed.; 1997.

32. Van't Spijker A. Psychologicalsequelae of cancer diagnosis: a meta-analytical review of 58 studies after 1980. In: R T, editor. 59 ed. Psychosom Med1997. p. 280-93.

33. Kaplan RM. Quality of life measurement. Em P Karoly, (Ed), Measurement Strategies in Health Psychology. New York: Pergamon Press1995.

34. Antonio R. Transtornos Depressivos. In: Moreno RA, editor. In: Abreu (Ed) Síndromes Psiquiátricas: diagnóstico e entrevista para profissionais de saúde mental. Porto Alegre: Artmed; 2006. p. 39-45.

35. Baptista MN, Santos. Auto-eficácia, lócus de controle e depressão em mulheres com câncer de mama. In: Santos KMaD, R. R, editor. Psicologia Argumento 2006. p. 27-36. 
36. Garcia MAA. A depressão em pacientes com câncer: In: Tafuri MJ, editor. Uma revisão; 2000.

37. Spoerri T. Introdução à Psiquiatria. $8^{\text {a }}$ ed. São Paulo, Atheneu, 2000. p. 107-8.

38. Bauer S. Da ansiedade à depressão - da psicofarmacologia à psicoterapia Ericksoniana. São Paulo: Livro Pleno, 2002.

39. Ballenger JC, Davidson JR, Lecrubier Y, Nutt DJ, Jones RD, Berard RM, et al. Consensus statement on depression, anxiety, and oncology. J Clin Psychiatry. 2001;62 Suppl 8:64-7.

40. Andrade L. Aspectos gerais das escalas de avaliação de ansiedade. In: Gorenstein, editor. Revista de Psiquiatria clínica; 2007. p. 285-90.

41. Avelar AM. Qualidade de vida, ansiedade e depressão em mulheres com câncer de mama antes e após a cirurgia. In: S. F. M. C, editor. Revista Ciência Médica; 2006. p. $11-20$.

42. Pimentel FL. Qualidade de Vida e Oncologia. Edições Almedina, AS Coimbra; 2006.

43. Sales CA. Qualidade de vida de mulheres tratadas de Câncer de mama. Funcionamento Social. Revista Brasileira de Cancerologia2001. p. 263-72.

44. Cella D.F. Quality of life during and after cancer treatment. In: Cherin EA, editor. Compr. Ther,1988. p. 69-75.

45. Aaronson NK, Ahmedzai S, Bergman B, Bullinger M, Cull A, Duez NJ, et al. The European Organization for Research and Treatment of Cancer QLQ-C30: a quality-oflife instrument for use in international clinical trials in oncology. J Natl Cancer Inst. 1993;85(5):365-76.

46. Aaronson NK. Quality of life of Cancer patients, Monographseries of the European Organization for Research on Treatment of Cancer (EORTC). In: Beckman J, editor. 17, Raven Press, New York.1987.Aaronson NK. Quality of life assessment in bladder cancer clinical trials: Conceptual, methodological and practical issues, Development in Bladder Cancer. In: Da Silva FC, Yoshida, O, editor. Alan R Liss, Inc,. New York,1986. p. 149-70.

47. Santos C. Estudo de adaptação da escala de qualidade de vida do familiar/cuidador do doente oncológico (CQOLC). In: Ribeiro JL, editor. Revista Portuguesa de Psicossomática2003. p. 105-18.

48. Selby P. Measurement of the quality of life. The particular problems of Cancer patients. Royal College of Physicians of London: London: Copyright; 1992. 
49. Albert US. Quality of life profile: from measure to clinical application. The Breast. 2002. p. 324-34.

50. Frans J.M. Grosfeld. Psychological risks of genetically testing children for a hereditary cancer syndrome Patient Education and Counseling 32. In: Am J Med Genet . 1997. p. 63-7.

51. Grosfeld FJ, Beemer FA, Lips CJ, Hendriks KS, ten Kroode HF. Parents' responses to disclosure of genetic test results of their children. Am J Med Genet. 2000;94(4):31623.

52. Grosfeld FJ, Lips CJ, Beemer FA, Blijham GH, Quirijnen JM, Mastenbroek MP, et al. Distress in MEN 2 family members and partners prior to DNA test disclosure. Multiple endocrine neoplasia type 2. Am J Med Genet. 2000;91(1):1-7.

53. M. C. Living with a hereditary form of cancer: experiences and needs of MEN2a patients and their families. In: Oskam W, editor. Henry Ford Hosp Med J 1989. p. 1646.

54. Motta PA. Genética em Psicologia. Rio de Janeiro:Guanabara Koogan1993.

55. Ellman R, Thomas B. Is psychological wellbeing impaired in long term survivors of breast cancer? J Med Screening 1995; 2:5-9.

56. Berglund G, Lidén A, Hansson MG, Oberg K, Sjöden PO, Nordin K. Quality of life in patients with multiple endocrine neoplasia type 1 (MEN 1). Fam Cancer. $2003 ; 2(1): 27-33$.

57. Larsson G, Sjoden P-O, Oberg K, Von-Essen L. importancesatisfaction discrepancies are associated with health-related quality of life in five-year survivors of endocrine gastrointestinal tumours. Ann Oncol 1999; 10: 1321-7.

58. Motta PA. Genética Humana aplicada à Psicologia, Enfermagem e fonoaudiologia. Rio de Janeiro: Guanabara Koogan1997.

59. Teixeira L. Os lugares do sofrimento e do processo de cura entre medicina e psicanálise. reflexões sobre a iatrogenia. 1 ed. Revista Universa: ciências biológicas, da saúde médica 2002. p. 81-94.

60. Zigmond AS, Snaith RP. The hospital anxiety and depression scale. Acta Psychiatr Scand. 1983;67(6):361-70.

61. Botega N.J. Transtornos do humor em enfermaria de clínica médica e validação de escala de medida (HAD) de ansiedade e depressão. In: Bio MR ZM, editor. Rev. Saúde Pública.,1995. p. 355-63. 
62. Botega N.J. Validação da escala hospitalar de ansiedade e depressão (HAD) em pacientes epiléticos ambulatoriais. In: Pondé MP, editor. 6 ed. J Bras Psiquiatr, 1998.

63. Brabo E.P. Validação para o Brasil do questionário de qualidade de vida para pacientes com câncer de pulmão (QLQ-LC13) da Organização Européia para Pesquisa e Tratamento do Câncer. [Dissertação]. Rio de Janeiro: UERJ, 2006.

64. Bowling A, Ebrahim S. Measuring patients' preferences for treatment and perceptions of risk. Qual Health Care. 2001;10 Suppl 1:i2-8.

65. Pais-Ribeiro JL. Contribuição para uma validação conservadora da escala reduzida de ajustamento mental ao cancro (Mini-MAC). In: Ramos D, editor. 2 ed. Psicologia, Saúde e Doenças. p. 231-47, 2003

66. Kirkwood BR, Sterne, AC. Essential medical statistics.2nd Ed. Blackwel Science:Massachusettss, USA. p.502, 2006.

67-Hosmer DW, Lemeshow, S. Applied LOgistic Regression. 2 ${ }^{\mathrm{a}}$.ed.New York:Wiley, 320p, 2000. 
ANEXO A 
Anexo A: Ficha de Informações Sociodemográficas e Entrevista Semi-Dirigida

Número do Protocolo:

Nome:

Telefone de Contato

Sexo ( )F eminino ( ) Masculino

data de nascimento:

RGHC-

Idade: $\_$anos.

Estado civil: (_ ) 1-Solteiro(a) ( ) 2-Casado (a) (_ ) 3-Com companheiro(a)

4-(_) Separado(a) (_) 5-Viúvo(a)

Número de anos de escolaridade:

Qual a sua ocupação- Profissão:

Está trabalhando atualmente?

1-Tem filhos?___ Se sim, quantos?

Se não, passar para a questão 7

2-Todos os filhos fizeram o teste genético para detectar a mutação do gene causador do NEM2?

Se não por quê?

3- Se sim: Tem filhos com diagnóstico de NEM2?

4- Se sim, qual a reação ao receber a informação de ter um filho afetado com a mesma doença que você?

5- Se sente culpado pelo seu filho também ter herdado a doença?

6- Como é o seu relacionamento com seus filhos?

Diagnóstico e Tratamento do NEM2

7- Qual sua reação ao saber que possui um câncer genético?

8-Qual o tipo de NEM2 possui?

9- Realizou cirurgia relacionada ao tratamento de MEN2?

9.1-Qual?

9.2-Quando?

10- Realizou ou realiza quimioterapia ou radioterapia devido ao tratamento de MEN2 ?

11-( ) 1-Vive sem doença （）2-Recidiva Local （）3-Metástase a distância

4-( ) Presença de FEOs ( ) Presença de carcinoma medular.

12- Toma todos os remédios prescritos pelo médico para o tratamento do MEN2?

Se não, por quê?

13- Sente-se bem informado pelo seu médico em relação a sua doença?

14- Como é para você ser portador de uma doença genética? 
Dados do Prontuário:

-Tipo de MEN2:

-Tipos de cirurgias realizadas:

-Realização de quimioterapia e radioterapia.

-Medicamentos utilizados no tratamento:

-Estágio da doença: 
ANEXO B 
A1 Eu me sinto tenso ou contraído:

3 ( ) A maior parte do tempo

2 ( ) Boa parte do tempo

1 ( ) De vez em quando

0 ( ) Nunca

D2 Ainda gosto das mesmas coisas de antes

0 ( ) Sim, do mesmo jeito que antes

1 ( ) Não tanto quanto antes 2 ( ) Só um pouco

3 ( ) Já não sinto mais prazer em nada

A3 Eu sinto uma espécie de medo como se alguma coisa ruim fosse acontecer

3 ( ) Sim, e de um jeito muito forte

2 ( ) Sim, mas não tão forte

1 ( ) Um pouco, mas isso não me preocupa

0 ( ) Não sinto nada disso

D4 Dou risadas e me divirto quando vejo coisas engraçadas

0 ( ) Do mesmo jeito que antes

1 ( ) Atualmente um pouco menos

2 ( ) Atualmente bem menos

3 ( ) Não consigo mais

A5 Estou com a cabeça cheia de

Preocupações

3 ( ) A maior parte do tempo

2 ( ) Boa parte do tempo

1 ( ) De vez em quando

0 ( ) Raramente

D6 Eu me sinto alegre

3 ( ) Nunca

2 ( ) Poucas vezes

1 ( ) Muitas vezes

0 ( ) A maior parte do tempo

A7 Consigo ficar a vontade e me sentir Relaxado

0 ( ) Sim, quase sempre

1 ( ) Muitas vezes

2 ( ) Poucas vezes

3 ( ) Nunca
D8 Eu estou lento para pensar e fazer coisas

3 ( ) Quase sempre

2 ( ) Muitas vezes

1 ( ) De vez em quando

0 ( ) Nunca

A 9 Eu tenho uma sensação ruim de medo, como um frio na barriga ou um aperto no estômago

0 ( ) Nunca

1 ( ) De vez em quando

2 ( ) Muitas vezes

3 ( ) Quase sempre

D10 Eu perdi o interesse em cuidar da minha aparência

3 ( ) Completamente

2 ( ) Não estou mais me cuidando como eu deveria

1 ( ) Talvez não tanto quanto antes

0 ( ) Me cuido do mesmo jeito que antes

A11 Eu me sinto inquieto, como se eu não pudesse ficar parado em nenhum lugar

3 ( ) Sim, demais

2 ( ) Bastante

1 ( ) Um pouco

0 ( ) Não me sinto assim

D12 Fico esperando animado as coisas boas que estão por vir

0 ( ) Do mesmo jeito que antes

1 ( ) Um pouco menos do que antes

2 ( ) Bem menos do que antes

3 ( ) Quase nunca

A13 De repente tenho a sensação de entrar em pânico

3 ( ) A quase todo momento

2 ( ) Várias vezes

1 ( ) De vez em quando

0 ( ) Não sinto isso

D14 Consigo sentir prazer quando assisto um bom programa de televisão, de rádio ou quando leio alguma coisa

0 ( ) Quase sempre

1 ( ) Várias vezes

2 ( ) Poucas vezes

3 ( ) Quase nunca 
ANEXO C 
Anexo C- 3.3- Scale Quality of Life for Patients with cancer (EORTC QLQ)-C30

\section{EORTC QLQ-C30 (version 3.0.)}

Nós estamos interessados em alguns dados sobre você e sua saúde. Responda, por favor, a todas as perguntas fazendo um círculo no número que melhor se aplica a você. Não há respostas certas ou erradas. A informação que você fornecer permanecerá estritamente confidencial.

Por favor, preencha suas iniciais:

Sua data de nascimento (dia, mês, ano):

Data de hoje (dia, mês, ano):

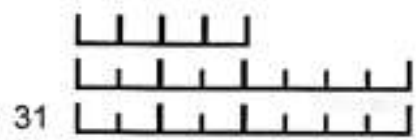

Não Pouco Modera- Muito damente

1. Você tem qualquer dificuldade quando faz grandes esforços, por exemplo carregar uma bolsa de compras pesada ou uma mala?

2. Você tem qualquer dificuldade quando faz uma grande caminhada?

$\begin{array}{llll}1 & 2 & 3 & 4 \\ 1 & 2 & 3 & 4\end{array}$

3. Você tem qualquer dificuldade quando faz uma curta caminhada fora de casa?

4. Você tem que ficar numa cama ou na cadeira durante o dia?

$\begin{array}{llll}1 & 2 & 3 & 4 \\ 1 & 2 & 3 & 4 \\ 1 & 2 & 3 & 4\end{array}$

\section{Durante a última semana:}

5. Tem sido dificil fazer suas atividades diárias?

Não Pouco Modera- Muito

Você precisa de ajuda para se alimentar, se vestir, se lavar ou usar o banheiro?

7. Tem sido dificil ter atividades de divertimento ou lazer?

3. Você teve falta de ar?

7. Você tem tido dor?

10. Você precisou repousar?

11. Você tem tido problemas para dormir?

12. Você tem se sentido fraco/a?

13. Você tem tido falta de apetite?

14. Você tem se sentido enjoado/a?

15. Você tem vomitado? 


\section{Durante a última semana:}

16. Você tem tido prisão de ventre?

17. Você tem tido diarréia?

18. Você esteve cansado/a?

19. A dor interferiu em suas atividades diárias?

20. Você tem tido dificuldade para se concentrar em coisas, como ler jornal ou ver televisão?

21. Você se sentiu nervoso/a?

22. Você esteve preocupado/a?

23. Você se sentiu irritado/a facilmente?

24. Você se sentiu deprimido/a?

25. Você tem tido dificuldade de se lembrar das coisas?

26. A sua condição fisica ou o tratamento médico tem interferido em sua vida familiar?

27. A sua condição fisica ou o tratamento médico tem interferido em suas atividades sociais?

28. A sua condição fisica ou o tratamento médico tem the trazido dificuldades financeiras?

\section{Não Pouco Modera- Muito damente}

$\begin{array}{llll}1 & 2 & 3 & 4 \\ 1 & 2 & 3 & 4 \\ 1 & 2 & 3 & 4 \\ 1 & 2 & 3 & 4\end{array}$

$\begin{array}{llll}1 & 2 & 3 & 4\end{array}$

$\begin{array}{llll}1 & 2 & 3 & 4\end{array}$

$\begin{array}{llll}1 & 2 & 3 & 4\end{array}$

$\begin{array}{llll}1 & 2 & 3 & 4\end{array}$

$\begin{array}{llll}1 & 2 & 3 & 4\end{array}$

$\begin{array}{llll}1 & 2 & 3 & 4\end{array}$

$\begin{array}{llll}1 & 2 & 3 & 4\end{array}$

$\begin{array}{llll}1 & 2 & 3 & 4\end{array}$

$\begin{array}{llll}1 & 2 & 3 & 4\end{array}$

Para as seguintes perguntas, por favor, faça um círculo em volta do número entre 1 e7 que melhor se aplica a você.

29. Como você classificaria a sua saúde em geral, durante a última semana?

$\begin{array}{llllllll}1 & 2 & 3 & 4 & 5 & 6 & 7\end{array}$

Péssima

Otima

30. Como você classificaria a sua qualidade de vida geral, durante a última semana?

$\begin{array}{llllllll}1 & 2 & 3 & 4 & 5 & 6 & 7\end{array}$

Péssima

Ótima 
ANEXOS D 
Anexo D- Escala de Ajustamento Mental para Câncer: Estudo Fatorial- (MINI- Leia todas as frases. Marque com um X resposta que melhor corresponder a que melhor se aplica a você.

1- Sinto que a vida não tem esperança.

)1= Não se aplica de modo nenhum a mim $\quad(\quad$ )2= Não se aplica a mim $\quad(\quad) 3=$ Aplica-se a mim ) $4=$ Aplica-se totalmente a mim.

2- Não consigo controlar isto.

( ) 1= Não se aplica de modo nenhum a mim ( )2= Não se aplica a mim ( ) $3=$ Aplica-se a mim ) = Aplica-se totalmente a mim.

3-. Estou determinado/a vencer a minha doença

( )1= Não se aplica de modo nenhum a mim $\quad(\quad) 2=$ Não se aplica a mim $\quad(\quad) 3=$ Aplica-se a mim ( ) $4=$ Aplica-se totalmente a mim.

4-. Faço um esforço positivo para não pensar na minha doença.

( )1= Não se aplica de modo nenhum a mim ( )2= Não se aplica a mim ( )3= Aplica-se a mim ( ) 4= Aplica-se totalmente a mim.

5. Desde que a minha doença foi diagnosticada, percebi que a vida é valiosa e estou a aproveitá-la da melhor forma possível.

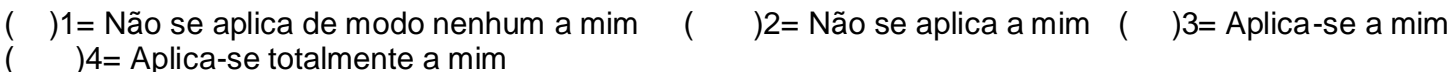

6. Não consigo lidar com isto.

)1= Não se aplica de modo nenhum a mim ( )2= Não se aplica a mim ( )3=Aplica-se a mim )4= Aplica-se totalmente a mim

7.Entreguei-me nas mãos de Deus.

( )1= Não se aplica de modo nenhum a mim ( )2= Não se aplica a mim ( )3= Aplica-se a mim ) = Aplica-se totalmente a mim

8. Estou preocupado/A com a minha doença.

( )1= Não se aplica de modo nenhum a mim ( )2= Não se aplica a mim ( )3= Aplica-se a mim ) = Aplica-se totalmente a mim

9-. Esforço-me por me distrair quando pensamentos acerca da minha doença me vêm à cabeça.

)1= Não se aplica de modo nenhum a mim $\quad(\quad$ )2= Não se aplica a mim $\quad(\quad$ )3= Aplica-se a mim

( )4= Aplica-se totalmente a mim. 
10- Estou preocupado que a doença volte a aparecer ou piore.

( ) 1= Não se aplica de modo nenhum a mim $\quad(\quad) 2=$ Não se aplica a mim $\quad(\quad) 3=$ Aplica-se a mim

( ) $4=$ Aplica-se totalmente a mim.

11-. Tive uma vida boa e o que vier daqui para frente é bem-vindo.

( ) 1= Não se aplica de modo nenhum a mim $\quad(\quad$ )2= Não se aplica a mim $\quad(\quad$ )3= Aplica-se a mim

( ) $4=$ Aplica-se totalmente a mim

12. Estou um pouco assustado/a.

( )1= Não se aplica de modo nenhum a mim $\quad(\quad$ )2= Não se aplica a mim $\quad(\quad) 3=$ Aplica-se a mim 4= Aplica-se totalmente a mim.

13- Sinto que não há nada que eu possa fazer que me ajude.

1= Não se aplica de modo nenhum a mim ( )2= Não se aplica a mim ( ) $3=$ Aplica-se a mim 4= Aplica-se totalmente a mim.

14- Tenho dificuldade em acreditar que isto tenha acontecido comigo.

( ) 1= Não se aplica de modo nenhum a mim $\quad(\quad$ )2= Não se aplica a mim $\quad(\quad$ )3= Aplica-se a mim

( ) $4=$ Aplica-se totalmente a mim

15-. Sofro de grande ansiedade por causa disto.

( ) 1= Não se aplica de modo nenhum a mim $\quad(\quad$ )2= Não se aplica a mim $\quad(\quad) 3=$ Aplica-se a mim

( ) $4=$ Aplica-se totalmente a mim.

16-. Não tenho muita esperança no futuro.

( )1= Não se aplica de modo nenhum a mim $\quad(\quad$ )2= Não se aplica a mim $\quad(\quad) 3=$ Aplica-se a mim

( ) 4= Aplica-se totalmente a mim.

17-.Neste momento vivo um dia de cada vez.

( ) 1= Não se aplica de modo nenhum a mim $\quad(\quad$ )2= Não se aplica a mim $\quad(\quad) 3=$ Aplica-se a mim ( ) 4= Aplica-se totalmente a mim

18. Apetece-me desistir.

( )1= Não se aplica de modo nenhum a mim $\quad(\quad$ )2= Não se aplica a mim $\quad(\quad) 3=$ Aplica-se a mim

( ) 4= Aplica-se totalmente a mim

19- Sinto-me muito otimista.

( )1= Não se aplica de modo nenhum a mim $\quad(\quad$ )2= Não se aplica a mim $\quad(\quad) 3=$ Aplica-se a mim

( ) $4=$ Aplica-se totalmente a mim

20-Encaro a minha doença como um desafio.

( ) 1= Não se aplica de modo nenhum a mim $\quad(\quad$ )2= Não se aplica a mim $\quad(\quad$ )3= Aplica-se a mim

$(\quad)$

4= Aplica-se totalmente a mim 
21- Não pensar na minha doença ajuda-me a lidar com isto.

( ) 1= Não se aplica de modo nenhum a mim $\quad(\quad$ ) $2=$ Não se aplica a mim $\quad(\quad) 3=$ Aplica-se a mim ( ) $4=$ Aplica-se totalmente a mim

22- Sinto-me completamente perdido sem saber o que fazer.

( ) 1= Não se aplica de modo nenhum a mim $\quad(\quad) 2=$ Não se aplica a mim $\quad(\quad) 3=$ Aplica-se a mim ( ) $4=$ Aplica-se totalmente a mim

23-Sinto-me muito zangado/a com o que me aconteceu.

( ) 1= Não se aplica de modo nenhum a mim $\quad(\quad) 2=$ Não se aplica a mim $\quad(\quad) 3=$ Aplica-se a mim ( ) 4= Aplica-se totalmente a mim

24. Intencionalmente empurro todos os meus pensamentos sobre a minha doença para longe.

) 1= Não se aplica de modo nenhum a mim

)4= Aplica-se totalmente a mim

25- Dou valor as coisas boas que me acontecem.

( ) $1=$ Não se aplica de modo nenhum a mim

( ) 4= Aplica-se totalmente a mim

26-. Tento combater a doença.

( ) 1= Não se aplica de modo nenhum a mim

( ) $4=$ Aplica-se totalmente a mim

27-Estou apreensivo/a

( ) 1= Não se aplica de modo nenhum a mim

( ) 4= Aplica-se totalmente a mim

28- Penso que isto é como se o mundo tivesse acabado

( ) 1= Não se aplica de modo nenhum a mim

( ) 4= Aplica-se totalmente a mim

)2= Não se aplica a mim ( )3= Aplica-se a mim

29. Sinto-me arrasado/a.

( ) 1= Não se aplica de modo nenhum a mim

( ) $4=$ Aplica-se totalmente a mim
$2=$ Não se aplica a mim ( $\quad 3=$ Aplica-se a mim

)2= Não se aplica a mim ( )3= Aplica-se a mim

22= Não se aplica a mim ( )3= Aplica-se a mim

22= Não se aplica a mim ( )3= Aplica-se a mim 
ANEXO E 
Anexo E: Termo de Consentimento Livre e Esclarecido HOSPITAL DAS CLÍNICAS DA FACULDADE DE MEDICINA DA UNIVERSIDADE DE SÃO PAULO-
HCFMUSP

TERMO DE CONSENTIMENTO LIVRE E ESCLARECIDO

DADOS DE IDENTIFICAÇÃO DO SUJEITO DA PESQUISA OU RESPONSÁVEL LEGAL

1. NOME:

2. DOCUMENTO DE IDENTIDADE № : SEXO :.$M \square \quad F$

DATA NASCIMENTO: ........................

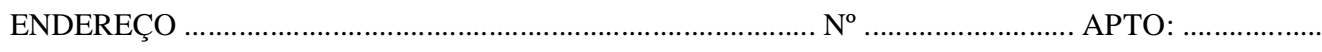

BAIRRO:

CIDADE

CEP:

TELEFONE: DDD

..)

2.RESPONSÁVEL LEGAL

NATUREZA (grau de parentesco, tutor, curador etc.)

DOCUMENTO DE IDENTIDADE :

SEXO: $\mathrm{M} \square \mathrm{F} \square$

DATA NASCIMENTO.: .....................

ENDEREÇO:

$\mathrm{N}^{\circ}$

APTO:

BAIRRO

CIDADE:

CEP:

TELEFONE: DDD (.............).

\section{DADOS SOBRE A PESQUISA}

1. TíTULO DO PROTOCOLO DE PESQUISA: Avaliação de Depressão, Ansiedade, Qualidade de Vida e Bem Estar Psicológico em Pacientes com Diagnóstico de Neoplasia Endócrina Múltipla Tipo 2.

PESQUISADOR: Karine Cândido Rodrigues

CARGO/FUNÇÃO: Mestranda da Faculdade de Medicina da Universidade de São Paulo- UNIDADE DO HCFMUSP: Endocrinologia

3. AVALIAÇÃO DO RISCO DA PESQUISA:

$\begin{array}{ll}\text { RISCO MÍNIMO } & X \quad \text { RISCO MÉDIO } \\ \text { RISCO BAIXO } \quad \square & \text { RISCO MAIOR }\end{array}$

4.DURAÇÃO DA PESQUISA : 24 meses

Este estudo tem como objetivos: avaliar a depressão e ansiedade, a qualidade de vida e o bem estarpsicológico em pacientes com diagnóstico de Neoplasia endócrina múltipla tipo 2. Se você concordar em participar deste estudo, será realizada uma entrevista semi-dirigida, e será pedido que você responda algumas questões que vão permitir avaliar as implicações na sua vida decorrentes do diagnóstico de uma doença transmitida geneticamente. Irá responder, também, algumas escalas que permitirão avaliar 
ansiedade e depressão, qualidade de vida e bem estar psicológico. A aplicação será realizada no ambulatório do HCFMUSP e terá duração de aproximadamente 1 hora. Não há riscos para os pacientes na aplicação deste protocolo de pesquisa. Se alguma das questões fizer com que você se sinta mal, você poderá se recusar a respondê-la a qualquer momento. Esse estudo tem como benefício a possibilidade de você ser encaminhada, se assim desejar, ao atendimento psicológico. Em qualquer etapa do estudo, você poderá ter acesso aos profissionais responsáveis pela pesquisa para esclarecimento de eventuais dúvidas. Os principais investigadores são Karine Cândido Rodrigues e Dr. Delmar M. Lourenço que podem ser encontrados no Departamento de Endocrinologia da Faculdade de Medicina da Universidade de São Paulo, Av. Dr. Arnaldo, 455. São Paulo, SP- Tel: 55-11-3061-7226

Se você tiver alguma consideração ou dúvida sobre a ética em pesquisa, entre em contato com o Comitê de Ética em Pesquisa (CEP) - Rua Ovídio Pires de Campos, 225 - 5º andar - tel: 3069-6442 ramais 16, 17, 18 ou 20, FAX: 3069-6442 ramais 16,17,18 ou 20, FAX: 3069-6442 ramal 26 - E-mail: cappesq@hcnet.usp.br. Você pode desistir de participar do estudo a qualquer momento sem que isso prejudique seu atendimento de saúde de boa qualidade. As informações obtidas serão analisadas em conjunto com outros pacientes, não sendo divulgada a identificação de nenhum paciente. Não há despesas pessoais para o participante em qualquer fase do estudo, também não há compensação financeira relacionada à sua participação. Todos os dados obtidos serão utilizados somente para esta pesquisa. Acredito ter sido suficientemente informado a respeito das informações que li ou que foram lidas para mim, descrevendo o estudo.

Eu discuti com a Karine Cândido Rodrigues sobre a minha decisão em participar nesse estudo. Ficaram claros para mim quais são os propósitos do estudo, os procedimentos a serem realizados, seus desconfortos e riscos, as garantias de confidencialidade e de esclarecimentos permanentes. Ficou claro, também, que minha participação é isenta de despesas e que tenho garantia do acesso a tratamento hospitalar quando necessário. Concordo voluntariamente em participar deste estudo e poderei retirar o meu consentimento a qualquer momento, antes ou durante o mesmo, sem penalidades ou prejuízo ou perda de qualquer benefício que eu possa ter adquirido, ou no meu atendimento neste serviço.

Assinatura do paciente/representante legal

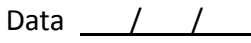

Assinatura da testemunha

Data

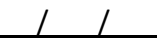

para casos de pacientes menores de 18 anos, analfabetos, semi-analfabetos ou portadores de deficiência auditiva ou visual.

(Somente para o responsável do projeto)

Declaro que obtive de forma apropriada e voluntária o Consentimento Livre e Esclarecido deste paciente ou representante legal para a participação neste estudo. 
